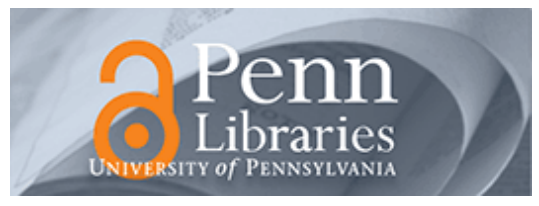

University of Pennsylvania

ScholarlyCommons

Accounting Papers

Wharton Faculty Research

8-2015

\title{
Corporate Governance, Incentives, and Tax Avoidance
}

Christopher S. Armstrong

University of Pennsylvania

Jennifer L. Blouin

University of Pennsylvania

Alan D. Jagolinzer

David F. Larcker

Follow this and additional works at: https://repository.upenn.edu/accounting_papers

Part of the Accounting Commons, and the Economics Commons

\section{Recommended Citation}

Armstrong, C. S., Blouin, J. L., Jagolinzer, A. D., \& Larcker, D. F. (2015). Corporate Governance, Incentives, and Tax Avoidance. Journal of Accounting and Economics, 60 (1), 1-17. http://dx.doi.org/10.1016/ j.jacceco.2015.02.003

This paper is posted at ScholarlyCommons. https://repository.upenn.edu/accounting_papers/19

For more information, please contact repository@pobox.upenn.edu. 


\title{
Corporate Governance, Incentives, and Tax Avoidance
}

\begin{abstract}
We examine the link between corporate governance, managerial incentives, and corporate tax avoidance. Similar to other investment opportunities that involve risky expected cash flows, unresolved agency problems may lead managers to engage in more or less corporate tax avoidance than shareholders would otherwise prefer. Consistent with the mixed results reported in prior studies, we find no relation between various corporate governance mechanisms and tax avoidance at the conditional mean and median of the tax avoidance distribution. However, using quantile regression, we find a positive relation between board independence and financial sophistication for low levels of tax avoidance, but a negative relation for high levels of tax avoidance. These results indicate that these governance attributes have a stronger relation with more extreme levels of tax avoidance, which are more likely to be symptomatic of over- and underinvestment by managers.
\end{abstract}

\section{Keywords}

tax aggressiveness, FIN 48, tax avoidance, CEO incentives, corporate governance

Disciplines

Accounting | Economics 


\title{
Corporate Governance, Incentives, and Tax Avoidance
}

\author{
Christopher S. Armstrong \\ The Wharton School \\ University of Pennsylvania \\ carms@wharton.upenn.edu \\ Jennifer L. Blouin ${ }^{*}$ \\ The Wharton School \\ University of Pennsylvania \\ blouin@wharton.upenn.edu \\ Alan D. Jagolinzer \\ Leeds School of Business \\ University of Colorado \\ jagolinzer@colorado.edu \\ David F. Larcker \\ Graduate School of Business \\ Rock Center for Corporate Governance \\ Stanford University \\ dlarcker@stanford.edu
}

February 2015

\begin{abstract}
We examine the link between corporate governance, managerial incentives, and corporate tax avoidance. Similar to other investment opportunities that involve risky expected cash flows, unresolved agency problems may lead managers to engage in more or less corporate tax avoidance than shareholders would otherwise prefer. Consistent with the mixed results reported in prior studies, we find no relation between various corporate governance mechanisms and tax avoidance at the conditional mean and median of the tax avoidance distribution. However, using quantile regression, we find a positive relation between board independence and financial sophistication for low levels of tax avoidance, but a negative relation for high levels of tax avoidance. These results indicate that these governance attributes have a stronger relation with more extreme levels of tax avoidance, which are more likely to be symptomatic of over- and under-investment by managers.
\end{abstract}

JEL: G34, H25, H26, K34, M41

Keywords: Tax aggressiveness; FIN 48; tax avoidance; CEO incentives; corporate governance

*Corresponding author

We thank Shane Heitzman and workshop participants at University of Delaware, ESADE, Goethe University, University of Iowa, the INSEAD research conference, University of Oregon, University of Toronto research conference, Texas A\&M University, Washington University, and Yale University for helpful comments. Jagolinzer thanks the EKS\&H Faculty Fellowship for financial support. Larcker thanks the Winnick Family Fund for financial support. 


\section{Introduction}

We examine the role of governance in tax planning decisions to help resolve the debate in the governance and tax literatures about whether a link exists between firms' corporate governance structures, including managers' incentive-compensation contracts, and corporate tax avoidance. The debate exists, in part, because prior research relies on Desai and Dharmapala's (2006) theory that provides counterintuitive predictions about the link between governance and tax avoidance decisions. In particular, Desai and Dharmapala (2006) argue that tax avoidance and managerial rent extraction can be complementary if tax avoidance reduces corporate transparency which, in turn, increases the opportunity for managers to divert corporate resources for personal benefit. Hence, their theory suggests that reducing tax planning can simultaneously reduce managerial diversion. Desai and Dharmapala further assume that well-governed firms are more likely to have internal control mechanisms to prevent such diversion and argue that a negative relation between managers' equity incentives and tax avoidance will only manifest in well-governed firms. In contrast, they assume that poorly governed firms will not use equity incentives to encourage tax avoidance because they lack the governance mechanisms to prevent managerial diversion.

While Desai and Dharmapala's theory is provocative, it has a number of important limitations. For example, Desai and Dharmapala fail to acknowledge that equity incentives are, themselves, an important governance mechanism (i.e., managers' equity incentives result from endogenous decisions by the board of directors that are, in part, aimed at mitigating agency problems). It is also unclear why well-governed firms would be more likely to rely on equity incentives than poorly-governed firms. If anything, prior studies suggest that managerial equity incentives can substitute for other governance mechanisms where more direct monitoring is 
either too costly or infeasible (e.g., Demsetz and Lehn, 1985; Core and Guay, 1999). Prior studies also suggest that poorly-governed firms (where managers have "control of the board") are more likely to over-pay managers in the form of equity (Bebchuk and Fried, 2004). Moreover, these same managers should have strong incentives to reduce tax payments and personally capture the resulting economic benefits (because of the lax oversight). Therefore, similar to their well-governed counterparts, poorly-governed firms should also exhibit a negative relation between equity incentives and tax avoidance. This chain of reasoning calls into question Desai and Dharmapala's conjecture that the relation between equity incentives and tax avoidance should only exist in well-governed firms.

In contrast to Desai and Dharmapala, we adopt a more traditional view of the role of governance on firms' tax avoidance. Under our alternative agency-theoretic view, tax avoidance is one of many risky investment opportunities available to management. Similar to other investment decisions, unresolved agency problems can lead managers to select a level of tax avoidance that differs from what shareholders would prefer. We do not assume that tax avoidance necessarily results in opportunities for managerial diversion. Rather, as with other agency problems, we assume that the various governance mechanisms in place, including managers' incentive-compensation contracts, can mitigate agency problems with respect to tax avoidance.

Other papers directly examine the link between corporate governance and tax avoidance. Minnick and Noga (2010) investigate whether several measures of corporate governance are associated with a variety of proxies intended to capture firms' level of tax avoidance, but find little evidence of a link. Rego and Wilson (2012) find that firms at which managers have relatively large risk-taking equity incentives engage in more tax avoidance. However, they fail to 
find evidence of a relation between other governance mechanisms and tax avoidance. Finally, in a concurrent study, Robinson et al. (2012) report evidence that audit committee financial expertise is generally positively associated with tax planning, but that this association is negative when tax planning is thought to be risky (i.e., aggressive). Overall, the relationships among corporate governance, managerial equity incentives, and tax avoidance are mixed and result in inconclusive inferences in the existing literature.

One common theme across prior studies is that inferences are based on estimates of how governance relates to the conditional mean of the tax avoidance distribution. However, the relationship between governance and the (conditional) average level of tax avoidance may not accurately describe the relationship in other parts of the tax avoidance distribution. Rather than rely solely on traditional econometric methods (i.e., ordinary least squares regression) that only provide estimates of the average relationship, we also estimate a series of quantile regressions to assess the relation across the entire tax avoidance distribution. This research design follows naturally from our conjecture that the relationship between corporate governance and tax avoidance will differ at relatively high and low levels of tax avoidance. In particular, boards that are more knowledgeable about the net benefits of tax strategies should encourage more tax planning at lower levels of tax avoidance because this improves cash flows with little accompanying risk. Conversely, more knowledgeable boards should discourage additional tax avoidance when the level is high because the increased costs (e.g., regulatory or reputational) are more likely to outweigh the marginal benefit of additional tax savings.

We examine a sample of firms between 2007 and 2011 and find that CEOs' risk-taking equity incentives exhibit a positive relationship with the average level (i.e., conditional mean) of tax avoidance. This result is analogous to the positive relationship between risk-taking equity 
incentives and earnings management reported by Armstrong et al. (2013) and is consistent with our characterization of tax avoidance as a risky positive expected net present value investment from the perspective of CEOs. More importantly, we find that this relationship is stronger for higher levels of tax avoidance, which suggests that managerial risk-taking incentives are an important determinant of aggressive tax positions that are likely to entail more risk.

We also examine how other governance mechanisms relate to observed levels of tax avoidance. In particular, we examine two important attributes of the board: financial expertise (to measure knowledge of the costs and benefits of tax avoidance) and independence (to measure the ability and incentive to monitor managers' tax avoidance decisions). We find that the relation between boards' financial expertise and independence and the level of tax avoidance differs considerably across the tax avoidance distribution. Specifically, we find that board financial expertise and independence both have a positive relation with tax avoidance for low levels of tax avoidance, which is consistent with under-investment in tax avoidance in the absence of monitoring. We also find that board financial expertise and independence both have a negative relation with tax avoidance for high levels of the tax avoidance, which is also consistent with over-investment in tax avoidance in the absence of monitoring. Collectively, these findings suggest that more financially sophisticated and more independent boards attenuate relatively extreme levels of tax avoidance, which are likely to be symptomatic of unresolved agency problems.

Because our findings are at odds with the predictions from Desai and Dharmapala's model, we attempt to reconcile the two sets of results. Consistent with Desai and Dharmapala (2006), we find that an interaction between an indicator of "good" governance and top executives' stock option compensation exhibits no relation with tax avoidance based on ordinary 
least squares estimates of the conditional mean. However, quantile regression estimates of their specification indicate a strong negative relation for high levels of tax avoidance and no relation for low levels. These estimates suggest that "good" corporate governance mitigates overinvestment in high levels of tax avoidance that would otherwise occur when executives receive large stock option grants. Thus, in contrast to Desai and Dharmapala (2006), we find that corporate governance appears to be related to managers' tax avoidance decisions, but only for high levels of tax avoidance. Importantly, this relationship is not apparent from examining the average level of tax avoidance. Our findings call into question whether tax avoidance and managerial rent extraction are, in fact, complementary activities as predicted by Desai and Dharmapala, and whether boards view them as such. If tax avoidance is instead better characterized as one of many alternative risky investment opportunities as our results suggest, then studies that interpret low levels of (i.e., underinvestment in) tax avoidance as a symptom of "good governance" should be reevaluated (e.g., Chen et al., 2010).

The remainder of the paper proceeds as follows. Section two discusses competing theories for the relation between corporate governance and tax avoidance and provides arguments for why the relation may vary for different levels of tax avoidance. Section three describes our sample. Section four discusses our research design and explains our choice of quantile regression estimation. Section five presents our primary empirical results and inferences. Section six discusses additional supplemental analysis and our reexamination of Desai and Dharmapala's (2006) findings. Section seven provides concluding remarks. 


\section{Prior Literature and Hypothesis Development}

\subsection{Prior Literature}

A mature stream of corporate tax research examines the determinants of effective tax rates and book-tax differences (e.g., Gupta and Newberry, 1997). Subsequent studies (e.g., Mills and Newberry, 2001 and Cloyd et al., 1996) focus on the book-tax tradeoffs that are associated with various tax avoidance opportunities (i.e., some tax avoidance strategies reduce both taxable and financial statement income, whereas others affect only taxable income). Although this prior research is useful, it provides little insight into why some firms engage in more tax planning than others (Shackelford and Shevlin, 2001).

This gap in the literature spurred a series of papers that more directly examine the determinants of corporate tax avoidance. ${ }^{1}$ For example, Dyreng et al. (2010) report evidence that executives who were previously employed by firms that are characterized as tax aggressive seem to import this aggressiveness to their new employer. Slemrod (2004), Crocker and Slemrod (2005), and Chen and Chu (2005) suggest that corporate tax noncompliance (i.e., extreme tax avoidance) could result from the tax reporting incentives provided by managers' incentivecompensation contracts. Consistent with this notion, there is empirical evidence that tax avoidance is associated with greater levels of incentive compensation (e.g., Phillips, 2003; Armstrong et al., 2012; Rego and Wilson, 2012).

There is little research that directly examines whether (or how) corporate governance affects tax avoidance. As discussed in the previous section, Desai and Dharmapala (2006)

\footnotetext{
${ }^{1}$ A related set of studies attempts to identify and validate measures of tax avoidance. For example, Frank et al. (2009), Wilson (2009), Lisowsky (2010), and Dyreng et al. (2008) develop alternative measures of tax avoidance. Since the passage of the Financial Accounting Standards Board (FASB)'s Interpretation No. 48 (Accounting for Uncertainty in Income Taxes) (hereafter FIN 48), several recent papers measure firms' tax aggressiveness using the magnitude of their uncertain tax benefits (e.g., Rego and Wilson, 2012; Lisowsky et al., 2013). As we discuss in more detail below, we carefully consider the specific attribute of tax avoidance that is called for by our research question (Hanlon and Heitzman, 2010).
} 
develop and test a model that links managers' equity-based compensation to aggressive tax avoidance. They conjecture the existence of complementarities between tax-sheltering and rent extraction. The essence of their argument is that managers of well-governed firms will have greater incentives for tax avoidance because the presence of other governance mechanisms will prevent these managers from extracting the rents that are generated from their tax avoidance activities. In contrast, managers of poorly-governed firms will not have incentives for aggressive tax avoidance because the lack of monitoring and oversight would otherwise allow these managers to extract the rents that are generated from their aggressive tax planning.

Recent work questions several of the fundamental assumptions in Desai and Dharmapala's model. For example, their model assumes that managers can extract rents generated by tax avoidance because operational complexity (and the accompanying information asymmetry) results in a more opaque information environment and therefore lowers the cost and expands the scope for rent extraction. However, Gallemore and Labro (2014) find that tax avoidance is associated with higher quality (internal) information environments and the precise channels through which managers extract (or personally benefit from) the rents that are generated from tax avoidance are not clear. Moreover, there is limited empirical evidence that managers do, in fact, extract rents that are generated by tax avoidance. ${ }^{2}$ Desai and Dharmapala (2006) also implicitly assume that equity-based compensation does not provide a direct, mechanical tax benefit in the form of a tax shield. Seidman and Stomberg (2011) challenge this assumption and find that firms with higher levels of equity-based compensation are less likely to benefit from additional tax avoidance. Seidman and Stomberg (2011) suggest that Desai and

\footnotetext{
${ }^{2}$ Desai et al. (2007) present evidence that Russian oligarchs appear to extract meaningful rents from firms that avoid more taxes. However, the authors do not find evidence that this is the case for Russian firms that operate in regulated (e.g., U.S.) markets. Blaylock (2011) also fails to find evidence that managers of U.S. firms extract economically meaningful rents through tax avoidance.
} 
Dharmapala's association between equity compensation and tax avoidance can be explained by "tax exhaustion."

In a related concurrent study, Robinson et al. (2012) also examine the association between incentives and governance for both general and "risky" forms of tax avoidance. ${ }^{4}$ Robinson et al. report that the proportion of accounting experts on the board is associated with more general and less "risky" tax planning. To the extent their measure of "risky" tax planning explains variation in relatively extreme levels of tax avoidance (i.e., the right tail of the tax avoidance distribution), our findings regarding the relation between board financial expertise and tax avoidance are consistent with those of Robinson et al. (2012). However, one important difference between our study and Robinson et al. is that we also examine the effect of governance and incentives on tax avoidance across the entire tax avoidance distribution, which provides better insight into the link between governance and tax avoidance. For example, firms in the left tail of the (conditional) tax avoidance distribution are those that engage in less tax avoidance than expected (i.e., "under-shelter"), and constitute an important and unresolved puzzle in the tax literature. ${ }^{5}$ Our findings also shed light on the relation between various governance mechanisms and tax avoidance of these firms.

In summary, although extant literature provides some insight into the role of incentives on tax avoidance, inferences are still limited regarding whether (and how) corporate governance

\footnotetext{
${ }^{3}$ Graham et al. (2006) suggest that firms require fewer alternative tax shelters if they utilize more stock option grants. This "tax exhaustion" occurs because option exercises provide the corporation with tax deductions, which reduces the need to engage in alternative tax avoidance strategies. The same reasoning can also be found in the equity incentives literature. For example, Core and Guay $(1999,159)$ argue that "when future corporate tax rates are expected to be higher, the future tax deduction from deferred compensation becomes more favorable relative to the immediate tax deduction received from cash compensation."

${ }^{4}$ Robinson et al. (2012) measure risky tax planning using estimates of tax shelter likelihood derived from the level of activity in tax havens (Dyreng and Lindsey, 2009; Balakrishnan et al., 2012) and the shelter estimation models described in Wilson (2009) and Lisowsky (2010). They also use the predicted uncertain tax benefits as an additional proxy for firms' involvement in risky tax planning following Cazier et al. (2009) and Rego and Wilson (2012).

${ }^{5}$ The lack of evidence of significant costs of tax avoidance is frequently referred to in the literature as the "undersheltering puzzle" (e.g., Desai and Dharmapala, 2006; Weisbach, 2002; Hanlon and Heitzman, 2010; and Gallemore et al., 2012).
} 
influences firms' tax avoidance. Moreover, the evidence that does exist is confined to explaining the conditional mean of the tax avoidance distribution, but does not describe the relation in other, potentially more interesting and informative parts of the distribution-most notably in the tails.

\subsection{Research hypotheses}

\subsubsection{Managerial incentives}

The majority of most CEOs' monetary incentives stem from changes in the value of their equity holdings. Prior studies discuss how the sensitivity of a CEO's equity portfolio to changes in stock price, or delta, has two opposing effects on their risky project selection decisions. On one hand, since delta captures the sensitivity of a CEO's wealth to stock price, it encourages CEOs to take risks that are expected to generate a sufficient increase in stock price. On the other hand, Armstrong et al. (2013) note that delta also "amplifies the effect of equity risk on the total riskiness of the manager's portfolio," which discourages risk-averse managers from pursuing risky projects. As a result of these two opposing effects, the net incentive effect of delta is theoretically ambiguous for risky projects. If CEOs believe that the increase in stock price will more than offset the accompanying increase in equity risk associated with aggressive tax positions, then delta should encourage tax avoidance. Alternatively, if CEOs believe that the risk to their equity wealth exceeds any increase in stock price from adopting aggressive tax positions, then delta should discourage tax avoidance. Because of these opposing effects, it is not clear whether CEOs' equity portfolio delta will be positively or negatively associated with tax avoidance across the distribution.

Unlike delta, the sensitivity of a CEO's equity portfolio value to changes in stock return volatility, or vega, provides them with an unambiguous incentive to take risk. ${ }^{6}$ Therefore, if

\footnotetext{
${ }^{6}$ Armstrong and Vashishtha (2012) develop a numerical example that shows that although equity portfolio vega provides risk-averse CEOs with incentives to take both systematic and idiosyncratic risk, the incentive to take 
CEOs believe that more aggressive tax avoidance increases stock price volatility, we expect vega to have a positive relation with tax avoidance. Moreover, the magnitude of this relation should be higher (lower) in the right (left) tail of the tax avoidance distribution where there is thought to be more (less) risk associated with the tax avoidance. This prediction is similar to that in Rego and Wilson (2012), except that we also predict a stronger relation at higher levels—and, conversely, a weaker relation at lower levels — of the tax avoidance distribution.

\subsubsection{Board characteristics}

Similar to other activities that entail both costs and benefits, the effect of tax avoidance on firm value should be concave with an interior optimum. In particular, there are likely to be positive net benefits (e.g., cash savings) from engaging in tax avoidance up to some firm-specific optimal level. Beyond this point, the marginal cost of additional tax avoidance (e.g., costs related to structuring complicated tax transactions, an inability to repatriate and invest foreign earnings, and potential political, regulatory, or reputational costs that are detrimental to future operations) exceeds the marginal benefit. ${ }^{7}$ If shareholders and managers have different preferences for tax avoidance then governance mechanisms will be used to influence managers' tax avoidance decisions. For example, certain governance mechanisms may prevent (or mitigate) over- and under-investment in tax avoidance. Although a firm's governance structure is comprised of a complex set of contracts, relationships, and institutional features, we focus on governance mechanisms that we believe are closely related to tax decisions. Specifically, we focus on the

systematic risk is stronger than the incentive to take idiosyncratic risk. Our analysis does not distinguish between the nature of the risk (i.e., systematic versus idiosyncratic) associated with tax avoidance and does not rely on the differential strength of risk-taking incentives provided by vega. Our analysis instead relies on vega providing CEOs with incentives to take both types of risk.

${ }^{7}$ For example, some studies suggest that firms incur potential tax penalties and reputational costs (e.g., Chen et al., 2010) or face significant costs defending aggressive tax positions (e.g., Rego and Wilson, 2012). Although there is little direct evidence supporting the existence of explicit reputational costs (e.g., Gallemore et al., 2012; Hanlon and Slemrod, 2009), there is clearly some underlying cost of extreme tax avoidance because not all firms have extremely low effective tax rates. 
financial sophistication and independence of the board. We expect that more financially sophisticated boards will be better able to monitor their firm's tax positions. This prediction is consistent with recent guidance that recommends that tax issues, including implementing and monitoring tax planning, should be placed on the audit committee's agenda and, more generally, advocates "greater awareness in the Boardroom of the importance of tax issues." Accordingly, we predict a positive (negative) relation between the financial sophistication of boards and tax avoidance in the left (right) tail of the tax avoidance distribution. The extent to which independent directors affect a firm's tax policy is not ex ante clear. Independent directors may not have sufficient firm-specific expertise to affect firm tax policy. Alternatively, they may be able to draw on outside experience with other firms' tax positions and therefore be more likely to influence tax planning activities. Independent directors should recognize that there are potential costs associated with extreme tax positions and, consequently, should attempt to mitigate extreme tax avoidance. If independent directors monitor managers' tax positions or are otherwise sensitive to extreme tax avoidance, then we expect to find a positive (negative) relation between board independence in the lower (upper) tail of the tax avoidance distribution.

\section{Sample Selection}

Our sample selection starts with all firms listed on Compustat for the 2007-2011 fiscal years for which we have data to compute at least one of the tax attributes that we define below. ${ }^{9}$ We eliminate foreign registrants and firms designated as real estate investment trusts (REITs) because these firms are subject to different tax rules. We also eliminate firms that have an annual

\footnotetext{
${ }^{8}$ See Jeffrey Owens, Good Corporate Governance: the Tax Dimension-OECD Forum on Tax Administration, September 2006 and Deloitte Hot Topics: Taxes: What the audit committee should know, October 2011.

9 As recommended by Lisowsky et al. (2013), we delete observations with missing Compustat data for ENDFIN48BAL. We also truncate ETR observations to be between zero and one. Because we use three-year ETRs, very few observations are truncated.
} 
average stock price of less than $\$ 1.00$ per share and firms with average total assets of less than $\$ 10,000$. These requirements yield 12,275 firm-year observations. We then retain firm-year observations for which we have data available for our control variables (defined below). This yields 7,231 firm-year observations. Finally, we retain firm-years for which we have data available for our governance and incentives variables. ${ }^{10}$ This yields a final sample of between 3,137 and 4,128 firm-year observations depending on the measure of tax avoidance.

Table 1 Panel A provides descriptive statistics for all of the variables used in our analysis including measures of tax avoidance, governance, incentives, and the control variables. Table 1 Panel B compares characteristics of our sample to those of the Compustat population for fiscal year 2009, which is the year that has the largest representation in our sample. Panel B shows that the firms in our sample are represented in each of the Barth et al. (1998) industry groups and, on average, are larger and more profitable than those in the broader Compustat population.

\section{Research Design}

Since our hypotheses relate to the extreme tails of the tax avoidance distribution, our primary statistical tests and inferences are based on quantile regression estimates. Quantile regression allows us to draw more complete inferences beyond those that can be drawn from traditional ordinary least squares (OLS) regressions, which only describe the relation between independent variables and the conditional mean of the dependent variable of interest. Quantile regression is more general and describes the relation between the independent variables and any specified percentile of the conditional distribution of the dependent variable. In describing the

\footnotetext{
${ }^{10}$ We obtain governance and incentives data from Equilar, which is similar to the ExecuComp database in that it provides executive compensation and equity holdings data collected from annual proxy filings (Form DEF 14A) with the SEC. We use Equilar data because it provides more than twice as many annual observations as ExecuComp.
} 
advantages of quantile regression, Hao and Naiman (2007) note that "the focus on the central location has long distracted researchers from using appropriate and relevant techniques to address research questions regarding noncentral locations on the response distribution. Using conditional-mean models (e.g., OLS regression) to address these questions may be inefficient or even miss the point of the research altogether. ...A set of equally spaced conditional quantiles can characterize the shape of the conditional distribution in addition to its central location."

The essential features of quantile regression can be illustrated through the following example. Suppose that a researcher is interested in determining whether education affects pay to help inform public policy regarding subsidized education. Further suppose that estimates from an OLS regression of pay on the level of education (e.g., years of schooling) indicate a small positive association between education and pay, leading the researcher to infer that the average effect of education on pay is modest. The policy recommendation based on inferences from OLS might be that further education investment generates only modest pay benefits. Quantile regression estimates at the conditional $5^{\text {th }}$ percentile of the pay distribution might instead reveal a much larger association between education and pay, suggesting that the returns to education are much larger for low-paid workers, who are more likely to receive educational subsidies.

In a related application, Eide and Showalter (1998) use quantile regression to determine whether the relation between school quality and standardized test performance differs across the conditional distribution of test performance. Their results indicate that per pupil expenditures "is a variable that is generally found to be insignificant in most regressions which focus on the mean effect. In the quantile regressions, the coefficient is ... insignificant at the 0.25 quantile and higher, but is relatively large and significant for the bottom tail of the distribution suggesting that these expenditures may increase math scores for the lower part of the conditional distribution." 
Quantile regression has also been applied in finance and economics to assess the effects of 401(K) participation on wealth (Chernozhukov and Hansen, 2004); the determinants of house prices (Zietz et al., 2008); the determinants of gender wage differences (Garcia et al., 2001); the effect of education on women's labor market value (Buchinsky, 2002); and to evaluate value-atrisk models (Gaglianone et al., 2011).

In our research setting, quantile regression allows us to determine whether the relation between various governance characteristics and tax avoidance varies across the tax avoidance distribution. As discussed in Section 2, we expect that more financially knowledgeable and more independent boards will more actively engage managers about their tax choices when the level of tax avoidance departs from the average. Thus, any relation between managerial incentives or corporate governance and tax avoidance should be more pronounced in the tails of the tax avoidance distribution. From a methodological perspective, this prediction implies that the impact of managerial incentives and related governance mechanisms will alter the shape of the entire tax avoidance distribution, rather than simply shift its central location as described by the mean or median. Consistent with some of the results from prior studies, it is possible that the impact of governance is slight or negligible at the mean or median, yet strong at other points of the tax avoidance distribution. Since traditional OLS regression estimation methods do not detect anything other than a shift in central location (i.e., the conditional mean), we use quantile regression as our primary method of estimation.

The basic intuition for quantile regression in the context of our hypotheses is illustrated in Figure 1. Conditioning on a particular governance mechanism may "rotate" the conditional tax avoidance cumulative distribution function (CDF) around the median in a counterclockwise manner. Such an effect would manifest as a negative (positive) coefficient on governance in the 
right (left) tail of the tax avoidance distribution. However, in this example, the coefficient on governance at the median (i.e., the central location) would be zero. Since traditional OLS and median regression only estimates the relationship at the "center" of the distribution (i.e., the mean and median, respectively), these techniques cannot detect shifts elsewhere in the distribution of interest and would not detect the shifts illustrated in Figure 1. In contrast, quantile regression is more general and describes changes in both the location and shape of the distribution of interest. ${ }^{11}$

\subsection{Quantile regression specification}

To test our research hypotheses, we estimate the following specification using quantile regression. $^{12}$

$$
\begin{aligned}
\text { TaxPosition }_{i, t}= & \beta_{0 i, t}+\beta_{1} \text { LogNumFinExp }_{i, t-1}+\beta_{2} \text { PctIndep }_{i, t-1}+ \\
& \beta_{3} \text { LogNumDirs }_{i, t-1}+\beta_{4} \text { LogCEOPortDelta }_{i, t-1}+ \\
& \beta_{5} \text { LogCEOPortVega }_{i, t-1}+\beta_{6} \text { CFOps }_{i, t}+ \\
& \beta_{7} \text { LogMVE }_{i, t}+\beta_{8} \text { LogForAssets }_{i, t}+\beta_{9} \text { GeoComp }_{i, t}+\varepsilon_{i, t},
\end{aligned}
$$

TaxPosition is one of two proxies that measure a firm's level of tax avoidance for a given year. Our first proxy for tax avoidance is EndFin48Bal, which we measure as the ending balance of the firm's uncertain tax benefit ("UTB") account (Compustat item TXTUBEND) scaled by total assets. The UTB represents management's estimate of the amount of tax savings generated by

\footnotetext{
${ }^{11}$ To better understand the technical aspects of quantile regression, recall that OLS regression minimizes the following loss function: $\min _{a, b} \sum_{i=1}^{N}\left(y_{i}-a-x_{i} b\right)^{2}$. Quantile regression is similar in that it minimizes an objective function with different weights for different quantiles. To illustrate, the special case of regression at the $50^{\text {th }}$ percentile (i.e., median regression) is described by the following objective: $\min _{a, b} \sum_{i=1}^{N}\left|y_{i}-a-x_{i} b\right|$. More generally, to estimate the association at any other specified percentile of the $Y$ distribution, quantile regression minimizes the following objective with asymmetric weights that are determined by the parameter $c$ : $\min _{\alpha \in \mathbb{R}, \beta \in \mathbb{R}^{K}} \sum_{i=1}^{N} c_{\tau}\left(y_{i}-\alpha-\boldsymbol{x}_{\boldsymbol{i}} \boldsymbol{\beta}\right)$, where $\tau$ is the quantile (i.e., percentile) of interest, $u$ is the error estimate, $c_{\tau}(u)=(\tau 1[u \geq 0]+(1-\tau) 1[u<0])|u|=(\tau-1[u<0]) u$, and $1\left[{ }^{*}\right]$ is the "indicator function" that equals one if the bracketed condition regarding $u$ is true and zero otherwise. (See Imbens, Guido W. and Jeffrey M. Wooldridge, 2007, Lecture Notes 14, Summer '07, available at http://www.nber.org/WNE/lect_14 quantile.pdf, for a further discussion.)

${ }^{12}$ Following Koenker and Hallock (2011), we both tabulate and graph the coefficient estimates at decile intervals to show the relationship across the entire support of the tax avoidance distribution. We also report OLS coefficient estimates of the conditional mean for comparative purposes.
} 
tax planning that is potentially payable to the tax authorities upon audit. Because the UTB represents an aggregation of multiple tax positions, it is highly visible to the board. In addition, directors can easily compare a firm's UTB to that of its peers to gauge whether management is over- or under-investing in tax planning.

Our second proxy for tax avoidance is TAETR, which is the difference between the firm's three-year average GAAP effective tax rate (hereafter, ETR, computed as the firm's total tax expense scaled by pre-tax income) and the three-year average GAAP ETR of the firm's size and industry peers (i.e., those in the same quintile of total assets in the same Fama-French 48 industry). This measure of tax avoidance captures cross-sectional variation in firms' total tax planning (including both timing and permanent differences), and benchmarks a given firm's tax aggressiveness relative to that of similar-sized firms in the same industry (see Balakrishnan et al., 2012). Similar to the UTB, a firm's ETR is a highly visible summary measure of tax planning that the board can monitor and evaluate. By comparing a firm's ETR to that of its peers, we are effectively performing a cross-sectional comparison that the board could make to determine whether the firm is investing too much or too little in tax planning activities. ${ }^{13}$

LogNumFinExp is the natural logarithm of one plus the number of financial experts on the board in the previous year (as indicated by RiskMetrics). We use the number rather than the proportion of financial experts on the board because we believe that the former better captures how the tax expertise of the board as a whole is determined by a subset of specialists. ${ }^{14}$ For example, we believe that a board with two financial experts out of ten total members is more

\footnotetext{
${ }^{13}$ One potential concern is that both of our measures of tax avoidance include accounting accruals. Accordingly, an alternative explanation of our results is that the boards do not monitor tax planning, but rather managers' accounting decisions. Although this explanation is consistent with our results, it is also requires that boards have detailed knowledge of their firm's tax positions to ascertain whether management's accounting choices are conservative (in the right tail) or aggressive (left tail).

${ }^{14}$ We observe similar results (untabulated) when we use the proportion rather than the number of financial experts on the board.
} 
likely to have more tax expertise than a board with one financial expert out of five total members. The proportion of financial experts, which is a common measure of boards' financial expertise, would treat these two scenarios as equivalent. However, we believe that the board has a better pool of expertise in the former scenario.

PctIndep is the proportion of independent directors in the previous year (as indicated by Equilar). LogNumDirs is the natural logarithm of one plus the total number of directors on the board in the previous year (as indicated by Equilar). LogCEOPortDelta is the natural logarithm of the (risk-neutral) dollar change in the CEO's equity portfolio value for a $1 \%$ increase in stock price (Core and Guay, 2002) during the previous year. As discussed earlier, portfolio delta measures the change in the CEO's wealth that relates to changes in stock price. LogCEOPortVega is the natural logarithm of one plus the (risk-neutral) dollar change in CEO equity portfolio value for a 0.01 increase in annual stock return volatility (Core and Guay, 2002) during the previous year. ${ }^{15}$ Portfolio vega measures the change in the CEO's wealth that relates to changes in stock price risk (i.e., return volatility).

We also control for economic determinants of firms' tax positions by including variables that are common in the tax literature that capture costs, benefits, and opportunities to engage in tax avoidance. CFOps is cash flow from operations divided by average total assets in the previous year; LogMVE is the natural logarithm of the firm's market value of equity in the previous year; LogForAssets is the natural logarithm of total foreign assets (Oler et al., 2007) in the previous year; GeoComp is a revenue-based Hirfindahl-Hirschman index that captures

\footnotetext{
${ }^{15}$ The value of a CEO's stock and restricted stock is assumed to change dollar-for-dollar with changes in the price of the underlying stock. The value of a CEO's stock options is assumed to change according to the option's delta (vega), which is the derivative of its Black-Scholes value with respect to price (return volatility). Annualized return volatility is calculated using continuously compounded monthly returns during the previous 36 months, with a minimum of 12 months of returns. The risk-free rate is calculated using the interpolated interest rate on a Treasury Note that is closest in maturity to the remaining life of the option multiplied by 0.70 to account for the prevalence of early option exercise. Dividend yield is calculated as the dividends paid during the previous twelve months scaled by the stock price at the beginning of the month.
} 
within-firm geographic segment complexity (Bushman et al., 2004) in the previous year; and $i$ and $t$ index the firm and fiscal year, respectively.

Panel $\mathrm{C}$ of Table 1 reports the mean values of CEO equity incentives (i.e., CEOPortDelta and CEOPortVega) for each decile of the unconditional tax avoidance distribution (where tax avoidance is measured as EndFin48Bal). Table 1 Panel $\mathrm{C}$ indicates that CEO equity incentives tend to increase with the level of tax avoidance. Table 1 Panel D reports Pearson correlations between the primary variables. Note that tax avoidance is associated with cash flow from operations, the amount of foreign assets, and the degree of geographic complexity, which underscores the importance of controlling for these factors in our multivariate specifications.

\section{Results}

Table 2 and Figure 2 present our primary results regarding the relation between corporate governance - including CEO equity incentives - and tax avoidance. We first consider the relation between CEO equity incentives and tax avoidance. OLS estimates of the conditional mean of tax avoidance presented in Panel A of Table 2 provide no evidence of a relation between TaxPosition and LogCEOPortDelta. In particular, the estimated coefficient is 0.0001 ( $t$-stat of 0.46) when tax avoidance is measured with EndFin48Bal and is -0.0035 ( $t$-stat of -1.56 ) when tax avoidance is measured as TAETR. Consistent with Rego and Wilson (2012), OLS estimates provide evidence of a positive relation between TaxPosition and LogCEOPortVega, particularly when tax avoidance is measured with EndFin48Bal (coefficient of 0.0004 and $t$-stat of 4.44).

Figure 2 Panel A plots the quantile regression coefficient estimates from Table 2 Panel A. In general, the patterns indicate that the relation between CEOs' equity incentives and tax avoidance is generally positive and increasing in magnitude in the right tail of the distribution. 
This pattern is particularly pronounced for LogCEOPortVega, which measures CEOs' equity risk-taking incentives. Tests of differences in coefficients across the quantiles when tax avoidance is measured as EndFin48Bal indicate that the coefficient at the $90^{\text {th }}$ percentile is significantly larger than the coefficient at the $50^{\text {th }}$ percentile ( $p$-value of 0.002 ), which, in turn, is significantly larger than the coefficient at the $10^{\text {th }}$ percentile ( $p$-value of 0.000 ). This observed positive relation is consistent with equity incentives being an important determinant of TaxPosition. Moreover, depending on whether observed equity incentives are "optimal," the large differences at the extremes of the tax aggressiveness distribution are consistent with unresolved agency problems with respect to tax avoidance.

Figure 2 Panel B and Table 2 Panel B both present results for the relation between tax avoidance and board expertise and independence. We focus first on LogNumFinExp, which is our proxy for the financial sophistication on the board. We expect that more sophisticated boards are better able to assess when the firm might be over- or under-investing in tax avoidance, and will therefore have a greater effect on the firm's tax avoidance at extreme levels of tax avoidance. Consequently, we expect to observe a positive relation between LogNumFinExp and TaxPosition in the left tail and a negative relation in the right tail of the tax avoidance distribution.

The OLS estimates in Panel B of Table 2 provide no evidence of a statistical relation between TaxPosition and LogNumFinExp for either tax avoidance measure. The OLS coefficient is -0.0009 ( $t$-stat of -0.96$)$ when EndFin48Bal is the measure of tax avoidance and is $-0.0089(t-$ stat of -1.08) when TAETR is the measure of tax avoidance. In contrast, Figure 2 shows that the relation between the financial expertise of the board and both measures of tax avoidance differs across their respective distributions. Specifically, the relation between financial expertise and tax 
avoidance is positive in the left tail but negative in the right tail. Tests of coefficient differences across quantiles indicate that the coefficient at the $90^{\text {th }}$ percentile ( $t$-stat of -1.94) is significantly more negative than the coefficient at both the $10^{\text {th }}(t$-stat of 5.58 , difference $p$-value of 0.014$)$ and the $50^{\text {th }}$ percentiles ( $t$-stat of 1.33 , difference $p$-value of 0.011) when EndFin48Bal is the measure of tax avoidance. This result is consistent with our hypothesis and indicates that boards' financial sophistication does not have a uniform relation with tax avoidance, but that the relation differs according to the level of tax avoidance. ${ }^{16}$ Moreover, the quantile regression estimates indicate that OLS estimates of the conditional mean are not representative of the relation at other points of the tax avoidance distribution. Therefore, generalizing based on OLS estimates of the conditional mean provides a misleading picture of the relation between this important governance mechanism and tax avoidance.

Next we consider PctIndep, which measures board independence and has been used as a proxy for the amount of board monitoring and oversight of management. Desai and Dharmapala (2006) suggest that agency problems may arise with respect to tax avoidance which would occur if shareholders and managers evaluate the costs and benefits of tax avoidance differently. If more independent boards can better identify and mitigate these agency problems, then we expect to observe a positive (negative) relation in the left (right) tail of the tax avoidance distribution.

The OLS estimates presented in Panel B of Table 2 provide no evidence of a relation between TaxPosition and PctIndep. The coefficient is -0.0014 ( $t$-stat of -0.46) when TaxPosition is measured with EndFin48Bal and 0.0103 ( $t$-stat of 0.37) when TaxPosition is measured with TAETR. However, similar to our results for LogNumFinExp, the quantile regression coefficient estimates in Table 2 and the corresponding graph in Figure 2 provide some evidence that the

\footnotetext{
${ }^{16}$ This result is consistent with the hypothesis that sophisticated board members affect tax policy decisions at extreme levels of tax avoidance. An alternative inference is that sophisticated directors do not affect tax policy decisions, but instead affect the tax accruals that are reported by managers.
} 
relation between board independence and tax avoidance differs across the tax avoidance distribution. Tests of coefficient differences across quantiles indicate that the coefficient at the $90^{\text {th }}$ percentile ( $t$-stat of -2.28$)$ is significantly more negative than the coefficient at the $50^{\text {th }}$ percentile ( $t$-stat of 2.01, difference $p$-value of 0.005$)$ when TAETR is the TaxPosition proxy. This pattern is consistent with our hypothesis that more independent boards alleviate over- and under-investment in tax avoidance, which is one potential symptom of unresolved agency problems with respect to tax planning.

Although the results in Table 2 and Figure 2 provide insight into the relation between firms' governance attributes and tax avoidance, we acknowledge that our inferences are limited because variation in firms' governance structures may not be exogenous with respect to their level of tax avoidance. Therefore, we cannot rule out the possibility that our inferences are confounded by reverse causality or more general concerns related to correlated omitted variables. We considered several ways to address these concerns. First we considered quantile regression with instrumental variables (e.g., Frolich and Melly, 2012; Kaplan and Sun, 2013; Powell, 2013). However, there is no obvious instrument that satisfies the necessary conditions of being both "relevant" (i.e., induces sufficient variation in firms' governance structures) and "valid" (i.e., satisfies the exclusion restriction that requires the instrument to affect firms' tax avoidance only through its effect on their governance structures). Similarly, we are not aware of a suitable exogenous shock or "natural experiment" during our sample period that might allow for identification of causal effects.

Regarding the potential for reverse causality, it could be the case that firms' governance structures are designed primarily to influence tax avoidance activity. We believe that tax planning is one of many factors that is considered when selecting the design and composition of 
the board and is therefore, at most, a second-order concern. ${ }^{17}$ Moreover, board composition and structure is typically quite stable over time and would therefore be unlikely to change-or at least change quickly_in response to changes in the firm's tax position. Nevertheless, it is possible that firms with more aggressive tax positions select more financially sophisticated directors specifically to oversee these tax positions. We believe that this scenario is unlikely because it predicts not only a positive relation between LogNumFinExp and TaxPosition at both high and low levels of tax avoidance, but also a larger positive relation for high levels of tax avoidance where financially sophisticated directors would be most beneficial. Our results are inconsistent with this scenario.

We also believe that our research design helps to establish the nature of causality because we are not aware of an obvious candidate for an omitted correlated variable that would induce a positive relation between LogNumFinExp and TaxPosition for low levels of tax avoidance, but a negative relation for high levels of tax avoidance. Nevertheless, as with every observational study, our inferences are inherently descriptive.

\section{Supplemental Analysis}

\subsection{Sensitivity analysis: alternative measures of investment}

As previously discussed, tax avoidance can be view as one of many possible alternative risky investment opportunities. If this characterization is accurate, other types of investment (e.g., capital expenditures and research and development) should exhibit relations that are similar to the one that we document between governance and tax avoidance. Specifically, the relation between board financial sophistication and other types of investment should differ across the

\footnotetext{
${ }^{17}$ This belief is supported by the recent guidance cited above (see supra note 8) that advocates "greater awareness in the Boardroom of the importance of tax issues."
} 
investment distribution. Consistent with this conjecture, the estimated coefficients from quantile regressions (untabulated) of $C A P E X$ and $R \& D$ exhibit patterns that are similar to those reported for Tax Avoidance in Figure 2. ${ }^{18}$ This finding suggests that board financial sophistication and independence may also ameliorate agency problems that are associated with extreme levels of these other risky investment decisions.

\subsection{Sensitivity analysis: evidence of mean reversion in extreme tax avoidance}

If financially sophisticated boards detect and mitigate over- and under-investment in tax avoidance, we expect to observe subsequent changes in tax avoidance. To test this conjecture, we sort EndFin48Bal ${ }_{t-1}$ into quintiles and examine whether there is a predictable change in the next period's ending FIN 48 balance $\left(\triangle\right.$ EndFin48Bal $\left._{t}\right)$. In other words, we examine whether firms with relatively high (low) levels of tax avoidance subsequently reduce (increase) tax avoidance. We then investigate whether this effect - if it exists - is more pronounced for firms that have more financial experts and a greater percentage of independent directors on the board.

In untabulated analysis, we find that firms in the lowest quintile of EndFin48Bal t-1 $_{1}$ experience an increase of 0.0015 in the following year when they have at least three financial experts on the board. We also find that firms with two or fewer financial experts experience a smaller-albeit not statistically different-increase of 0.0008 in the following year. Conversely, we find that firms in the highest quintile of EndFin48Bal ${ }_{t-1}$ experience a decrease of -0.0054 in the following year when they have at least three financial experts on the board, and a significantly smaller decrease of -0.0011 when there are two or fewer financial experts on the board.

\footnotetext{
${ }^{18}$ We do not observe a similar pattern when ROA is the dependent variable, which suggests that we are not simply documenting quantile regression coefficient patterns that are spurious or mechanically determined by a particular research design choice.
} 


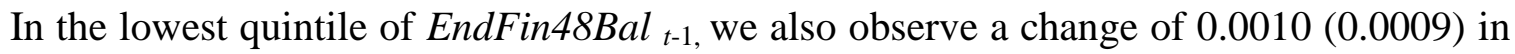
the following year when the percentage of independent directors on the board is greater (less) than the sample median. These changes are not statistically different from each other. In the highest quintile, we observe a $-0.0028(-0.0017)$ change in the following year when the percentage of independent directors on the board is greater (less) than the sample median. The difference between these changes is marginally significant. Collectively, these results are consistent with our conjecture that more financially sophisticated and more independent boards are associated with attenuated changes in relatively extreme levels of tax avoidance. ${ }^{19}$

\subsection{Re-examining Desai and Dharmapala (2006)}

Desai and Dharmapala (2006) present evidence that their measures of governance and equity-based compensation have an interactive effect on the average level of tax aggression. Specifically, they provide evidence (in their Table 4) that there is no statistical relation between tax aggressiveness and equity incentives-measured as the annual value of stock option grants scaled by total compensation of the firm's top five executives - in "well governed" firms (i.e., firms with low scores on a governance index). ${ }^{20}$ However, they report a significant negative relation between tax aggressiveness and equity-based compensation in "poorly governed" firms.

Desai and Dharmapala (2006) discuss why it is ambiguous whether equity-based compensation provides incentives for managers to engage in more or less aggressive tax strategies. They also discuss how it is reasonable to expect that the incentives for tax aggressiveness provided by equity-based compensation depend on the firm's other governance

\footnotetext{
${ }^{19} \mathrm{We}$ also attempt to assess the relation between changes in the number of financial experts on the board and subsequent changes in EndFin48Bal. However, there is little variation in the former measure, and the resulting test lacked sufficient power.

${ }^{20}$ Desai and Dharmapala (2006) measure tax aggressiveness as the residual from a regression of the difference between book and taxable income on total accruals (see their discussion, pp. 159-160). They also rely on the Gompers et al. (2003) "G-index", which is primarily a measure of shareholder rights with respect to takeovers, as their measure of governance quality. We believe that there are more relevant measures of governance quality available, particularly as it pertains to firms' tax avoidance.
} 
mechanisms, which can provide either reinforcing or countervailing incentives in the case of complements and substitutes, respectively. However, they neither model these complex interactions in their research design nor consider whether the relation might differ across the tax avoidance distribution. We estimate Desai and Dharmapala's (2006) primary empirical specification (i.e., their Table 4 Column (4)) using quantile regression to determine whether the relation that they document for the conditional mean is representative of the relation elsewhere in the distribution or whether the relation instead differs across the distribution, as our earlier findings suggest.

Figure 3 and Table 3 provide OLS and quantile regression estimates of Desai and Dharmapala's specification for our sample. Our OLS estimates are generally similar to those reported in Desai and Dharmapala. Importantly, we are able to replicate their result of a (marginally significant) negative coefficient on their measure of equity-based compensation and a positive (but insignificant) coefficient when this variable is interacted with an indicator for whether the firm is "well governed." Quantile regression estimates, however, show that the interaction between equity-based compensation and "good governance" differs-and, importantly, leads to different inferences — across the tax avoidance distribution. Specifically, we find that the relation is negative in the right tail of the tax avoidance distribution, which suggests that both equity incentives and certain governance mechanisms may, in fact, attenuate aggressive tax positions. These results and the corresponding inferences are inconsistent with Desai and Dharmapala's conclusion, but are in line with our results reported in Figure 2 and Table 2. Moreover, these results further illustrate the importance of examining how governance relates to tax avoidance across its entire distribution to gain a more complete understanding of the nature of their relationship. 


\section{Conclusion}

We examine the relation between corporate tax avoidance and corporate governance characteristics and managers' equity incentives. We expand the scope of prior research by estimating the relation not only at the conditional mean, but also across the entire tax avoidance distribution. Our specific research question relates to the tails of the tax avoidance distribution, which represent relatively extreme levels of tax avoidance. The ability to document shifts in the relation is particularly important in our research setting because certain governance mechanisms are likely to exhibit different relations with tax avoidance at different points in the distributionespecially if the net benefits of tax avoidance differ at different levels of tax avoidance.

Consistent with the hypothesis that managers expect greater personal benefits from increased tax avoidance (e.g., Rego and Wilson, 2012), we find evidence that risk-taking equity incentives are positively related to tax avoidance and that this relation is stronger in the right tail of the tax avoidance distribution. This result is consistent with the notion that relatively high levels of risk-taking equity incentives have the potential to motivate managers to invest in risky tax avoidance beyond the level that is desired by shareholders. We also find evidence that board financial sophistication and independence exhibit a positive (negative) relation with tax avoidance in the left (right) tail of the tax avoidance distribution. This finding is consistent with the hypothesis that more financially sophisticated and more independent boards mitigate agency problems related to relatively extreme levels of tax aggressiveness.

Collectively, our results provide yield a more nuanced understanding of how managerial incentives and certain corporate governance mechanisms are related to the level of corporate tax avoidance. Our results are also consistent with the notion that, similar to other investments that 
entail a risk-return tradeoff (i.e., costs and benefits), the optimal level of tax avoidance is unlikely to be at the "corner." Instead, the optimal level of tax avoidance is more likely to occur at an interior point at which the marginal costs and benefits (to managers) equate. 


\section{References}

Angrist, J. D. and J. S. Pischke, 2009. Mostly harmless econometrics. Princeton University Press.

Armstrong, C., Blouin, J., D. Larcker, 2012. The incentives for tax planning. Journal of Accounting and Economics 53(1): 391-411.

Armstrong, C., Jagolinzer, A. D., and D. F. Larcker, 2010. Chief Executive Officer Equity Incentives and Accounting Irregularities. Journal of Accounting Research 48: 225-271.

Armstrong, C., Guay, W. R., and J. P. Weber, 2011. The role of information and financial reporting in corporate governance and debt contracting. Journal of Accounting and Economics 50: 179-234.

Armstrong, C., Larcker, D. F., Ormazabal, G., and D. J. Taylor, 2013. The relation between equity incentives and misreporting: the role of risk-taking incentives. Journal of Financial Economics 109: $327-350$.

Armstrong, C., and R. Vashishtha, 2012. Executive stock options, differential risk-taking incentives, and firm value. Journal of Financial Economics 104: 70-88.

Balakrishnan, K., Blouin, J., and W. Guay, 2012. Does tax aggressiveness reduce corporate transparency? Working paper, University of Pennsylvania.

Barth, M., Beaver, W., and W. Landsman, 1998. Relative valuation roles of equity book value and net income as a function of financial health. Journal of Accounting and Economics 25: 1-34.

Bebchuk, L., and J. Fried, 2006. Pay without performance. The unfulfilled promise of executive compensation. Harvard University Press, Cambridge.

Blaylock, B., 2011. Do managers extract economically significant rents through tax aggressive transactions? Working paper, Oklahoma State University.

Buchinsky, M., 2002. Quantile regression with sample selection: Estimating women's return to education in the U.S. Economic Applications of Quantile Regression, Physica-Verlag HD.

Bushman, R., Chen, Q., Engel, E., and A. Smith, 2004. Financial accounting information, organizational complexity and corporate governance systems. Journal of Accounting and Economics 37: 167-201.

Cazier, R., Rego, S., Tian, X., and R. Wilson, 2009. Did FIN 48 limit the use of tax reserves as a tool for earnings management? Working paper, Texas Christian University.

Chen, K. P. and C. Y. C. Chu, 2005. Internal control vs. external manipulation: a model of corporate income tax evasion. RAND Journal of Economics 36: 151-164.

Chen, S., Chen, X., Cheng, Q., and T. Shevlin, 2010. Are family firms more tax aggressive than nonfamily firms? Journal of Financial Economics 95: 41-61.

Chernozhukov, V., and C. Hansen, 2004. The effects of 401(K) participation on the wealth distribution: An instrumental quantile regression analysis. The Review of Economics and Statistics 86: 735-751.

Cloyd, C. B., Pratt, J., and T. Stock, 1996. The use of financial accounting choice to support aggressive tax positions: public and private firms. Journal of Accounting Research 34: 23-43.

Core, J.E., and W. R. Guay, 1999. The use of equity grants to manage optimal equity incentive levels. Journal of Accounting and Economics 28: 151-184.

Core, J. E., and W. R. Guay, 2002. Estimating the value of employee stock option portfolios and their sensitivities to price and volatility. Journal of Accounting Research 40: 613-630.

Crocker, K. and J. Slemrod, 2005. Corporate tax evasion with agency costs. Journal of Public Economics 89: $1593-1610$.

Demsetz, H. and K. Lehn, 1985. The structure of corporate ownership: causes and consequences. Journal of Political Economy 93: 1155-1177.

Desai M. A., and D. Dharmapala, 2006. Corporate tax avoidance and high-powered incentives. Journal of Financial Economics 79: 145-179. 
Desai M. A., and D. Dharmapala, 2008. Taxation and corporate governance: An economic approach. Max Planck Institute Studies on Intellectual Property, Competition and Tax Law, (ed. Wolfgang Schon), Volume 3, 13-30.

Desai M. A., and D. Dharmapala, 2009. Corporate tax avoidance and firm value. Review of Economics and Statistics 91(3), 537-546.

Desai, M., and A. Dyck, and L. Zingales. 2007. Theft and taxes. Journal of Financial Economics 84, 591623.

De Waegenaere, A., R. Sansing, and J. Wielhouwer. 2010. Financial accounting measures of tax reporting aggressiveness. Working paper, Tilburg University.

Dyreng, S., M. Hanlon and E. Maydew, 2008. Long-run corporate tax avoidance. The Accounting Review 83: 61-82.

Dyreng, S., and B. Lindsey, 2009. Using financial accounting data to examine the effect of foreign operations located in tax havens and other countries on U.S. multinational firms' tax rates. Journal of Accounting Research 47: 1283-1316.

Dyreng, S., M. Hanlon and E. Maydew, 2010. The effects of managers on corporate tax avoidance. The Accounting Review 85: 1163-1189.

Eide, E. and M. Showalter, 1998. The effect of school quality on student performance: A quantile regression approach. Economics Letters 58: 345-350.

Fich, E. M. and A. Shivdasani, 2006. Are busy boards effective monitors? Journal of Finance 61: 689724.

Frank, M. M., Lynch, L., and S. Rego, 2009. Tax reporting aggressiveness and its relation to aggressive financial reporting. The Accounting Review 84: 467-496.

Frolich, M., and B. Melly, 2012. Unconditional quantile treatment effects under endogeneity. Working paper, Universitat Mannheim.

Gaglianone, W., Lima, L., Linton, O., and D. Smith, 2011. Evaluating value-at-risk models via quantile regression. Journal of Business \& Economic Statistics 29: 150-160.

Gallemore, J., and E. Labro, 2015. The importance of the internal information environment for tax avoidance. Journal of Accounting and Economics, forthcoming.

Gallemore, J., Maydew, E. L., and J. R. Thornock, 2012. The reputational costs of tax avoidance and the under-sheltering puzzle. Working paper, the University of North Carolina.

Garcia, J., Hernandez, P., and A. Lopez-Nicolas, 2001. How wide is the gap? An investigation of gender wage differences using quantile regression. Empirical Economics 26: 149-167.

Gompers, P., J. Ishii, and A. Metrick, 2003. Corporate governance and equity prices. The Quarterly Journal of Economics February: 107-155.

Graham, J., and A. Tucker, 2006. Tax shelters and corporate debt policy. Journal of Financial Economics 81: 563-594.

Gupta, S. and K. Newberry, 1997. Determinants of the variability in corporate effective tax rates: evidence from longitudinal data. Journal of Accounting and Public Policy 16: 1-34.

Hanlon, M. and J. Slemrod, 2009. What does tax aggressiveness signal? Evidence from stock price reactions to news about tax shelter improvement. Journal of Public Economics 93: 126-141.

Hanlon, M. and S. Heitzman, 2010. A review of tax research. Journal of Accounting and Economics 50: 127-178.

Hanlon, M., Mills, L., and J. Slemrod, 2007. An empirical examination of corporate tax noncompliance. Taxing Corporate Income in the 21 st Century, Cambridge: Cambridge University Press.

Hao, L., and D. Q. Naiman, 2007. Quantile regression. Sage publishing. 
Harris, M. and A. Raviv, 2008. A theory of board control and size. Review of Financial Studies 21: 17971832.

Ho, D. E., Imai, K., King, G., and E. A. Stuart, 2007. Matching as nonparametric preprocessing for reducing model dependence in parametric causal inference. Political Analysis 15: 199-236.

Kaplan, D., and Y. Sun, 2013. Smoothed Estimating Equations for Instrumental Variables Quantile Regression. Working paper, University of Missouri.

Koenker, R., and K. F. Hallock, 2011. Quantile regression. Journal of Economic Perspectives 15: 143156.

Larcker, D., and T. Rusticus, 2010. On the use of instrumental variables in accounting research. Journal of Accounting and Economics 49: 186-205.

Lisowsky, P., 2010. Seeking shelter: Empirically modeling tax shelters using financial statement information. The Accounting Review 85: 1693-1720.

Lisowky, P., L. Robinson and A. Schmidt, 2013. Do publicly disclosed tax reserves tell us about privately disclosed tax shelter activity? Journal of Accounting Research 51: 583-629.

Mills, L. and K. Newberry, 2001. The influence of tax and nontax costs on book-tax reporting differences: public and private firms. Journal of the American Taxation Association 23: 1-19.

Minnick, K. and T. Noga, 2010. Do corporate governance characteristics influence tax management? Journal of Corporate Finance 16, 703-718.

Oler, M., Shevlin, T., and R. Wilson, 2007. Examining investor expectations concerning tax savings on the repatriations of foreign earnings under the American Jobs Creation Act of 2004. Journal of the American Taxation Association 29: 25-55.

Phillips, J. D., 2003. Corporate tax planning effectiveness: the role of compensation-based incentives. The Accounting Review 78: 847-874.

Powell, D., 2013. A new framework for estimation of quantile treatment effects: nonseparable disturbance in the presence of covariates. Working paper, Rand Corporation.

Rego, S. O., and R. Wilson, 2012. Equity risk incentives and corporate tax aggressiveness. Journal of Accounting Research 50: 775-810.

Robinson, J. R., Xue, Y., and M. H. Zhang, 2012. Tax planning and financial expertise in the audit committee. Working paper, University of Texas at Austin.

Scholes, M. S., Wolfson, M. A., Erickson, M. M., Maydew, E. L., and T. J. Shevlin, 2009. Taxes and business strategy: a planning approach, Prentice Hall.

Seidman, J. and B. Stomberg, 2011. Why are option compensation and tax sheltering negatively related? Working paper, University of Texas.

Shevlin, T., 2007. The future of tax research: From an accounting professor's perspective. Journal of the American Taxation Association 29: 87-93.

Shevlin, T. and D. A. Shackelford, 2001. Empirical tax research in accounting. Journal of Accounting and Economics 31: 321-387.

Slemrod, J., 2004. The economics of corporate tax selfishness. National Tax Journal 57:877-899.

Weisbach, D., 2002. Ten truths about tax shelters. Tax Law Review 55: 215-253.

Wilson, R. 2009. An examination of corporate tax shelter participants. The Accounting Review 84(3), 969-999.

Zietz, J., Zietz, E., and G. Sirmans, 2008. Determinants of house prices: A quantile regression approach. Journal of Real Estate Finance and Economics 37: 317-333. 


\section{Figure 1}

\section{Example of the Effect of Governance on the Tax Avoidance Distribution}

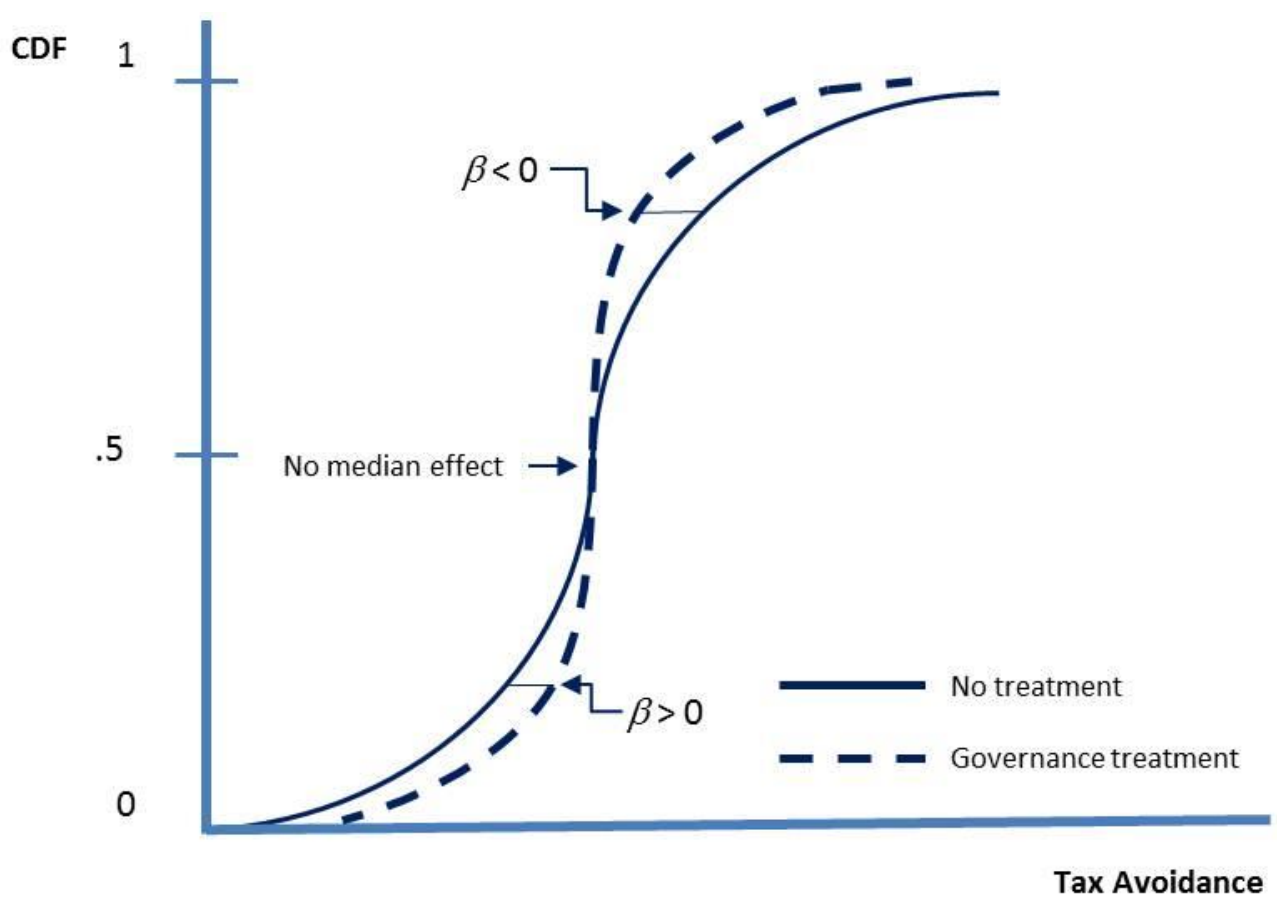

This figure illustrates the basic intuition for quantile regression in the context of the relation between Governance and Tax Avoidance. The treatment effect of a particular governance mechanism may "rotate" the conditional tax avoidance cumulative distribution function (CDF) around the median in a counterclockwise manner. Such an effect would manifest as a negative (positive) coefficient on governance in the right (left) tail of the tax avoidance distribution. However, the coefficient on governance at the median (i.e., the central location) would be zero. Since traditional OLS or median regression only estimates the relationship at the "center" of the distribution (i.e., the mean and median, respectively), these techniques cannot detect shifts that occur in other locations of the distribution of interest. In contrast, quantile regression is much more general and is designed to characterize changes in both the location and shape of the distribution of interest. 
Figure 2

\section{Coefficient Estimates at Various Quantiles of the Tax Avoidance Distribution}

Panel A: CEO Incentives

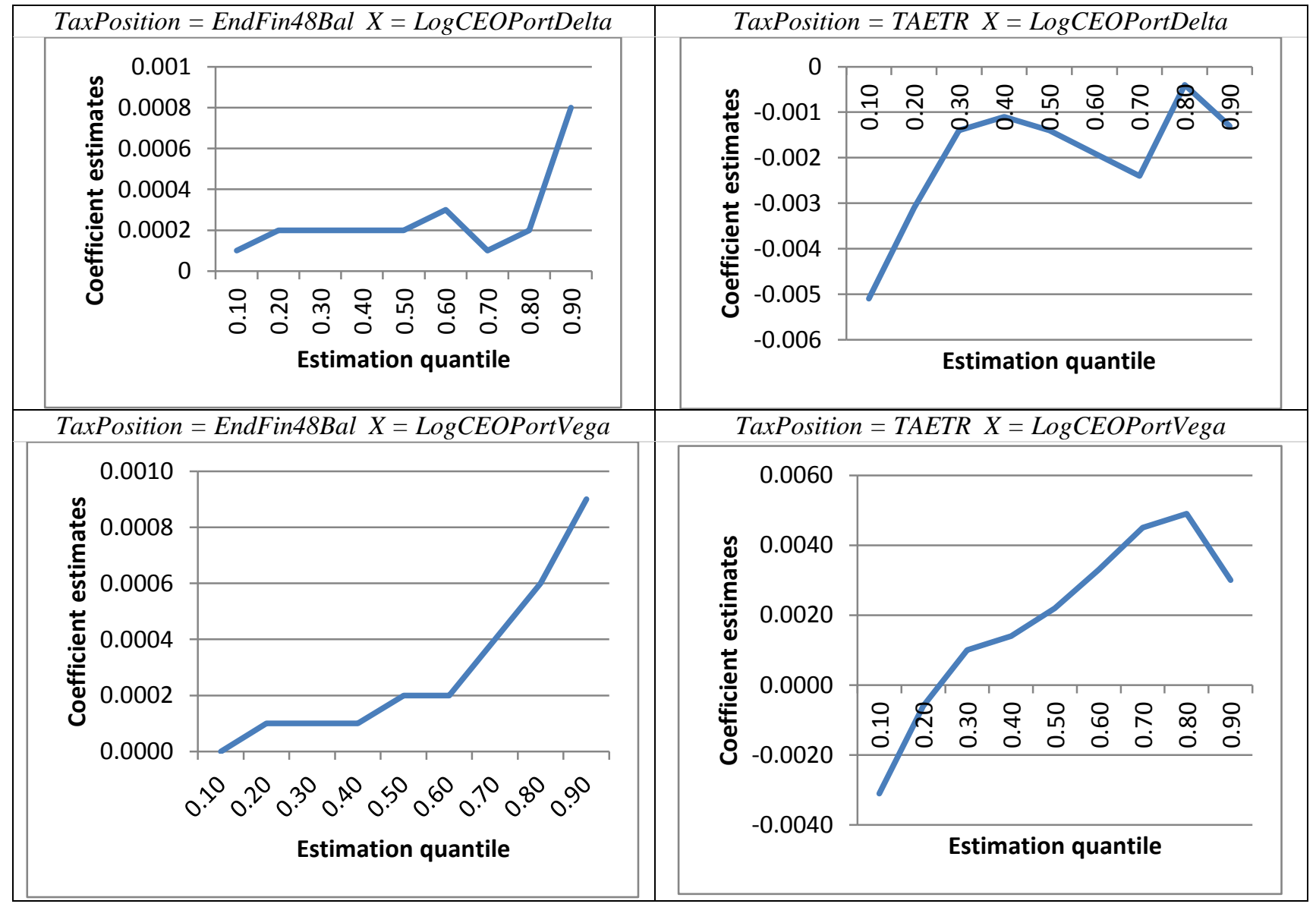




\section{Figure 2 (cont'd)}

Panel B: Board Expertise and Independence

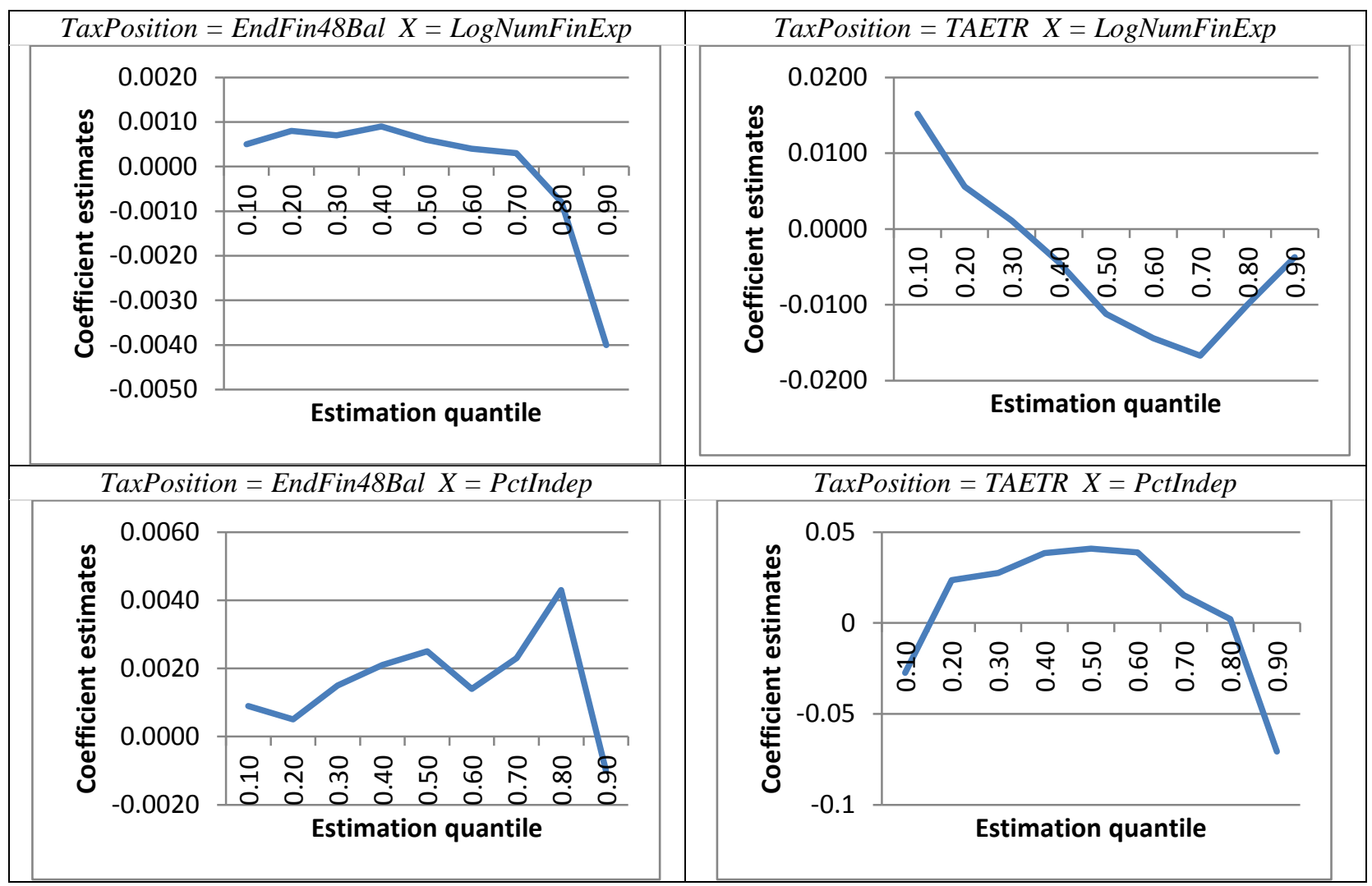

This figure plots quantile regression coefficient estimates at various quantiles of the tax avoidance distribution. Panels A and B correspond to estimates reported in Panels A and B of Table 2. EndFin48Bal is measured as the firm's ending balance of the uncertain tax benefit account (Compustat TXTUBEND), scaled by the firm's average assets over the period. TAETR is computed as the mean three-year GAAP ETR (computed as the firm's total tax expense scaled by pre-tax income) of the firm's size and industry peers minus the firm's three-year GAAP ETR. Size peers are firms within the same quintile of total assets and industry peers are firms within the same Fama-French 48 industry portfolios. PctIndep is the percentage of independent directors to total directors sitting on the board in the previous year (as indicated by Equilar). LogNumFinExp is the natural logarithm of one plus the number of financial experts designated on the board of directors in the year preceding the fiscal year (as indicated by RiskMetrics). CEOPortDelta (CEOPortVega) is the (risk-neutral) dollar change in the firm CEO's equity portfolio value for a $1 \%$ change in the value (volatility) of the firm's stock price (Core and Guay, 2002). LogCEOPortDelta (LogCEOPortVega) is the natural logarithm of CEOPortDelta (CEOPortVega). 
Figure 3

\section{Desai and Dharmapala (2006) Quantile Regression}

Table 4 (All Firms)

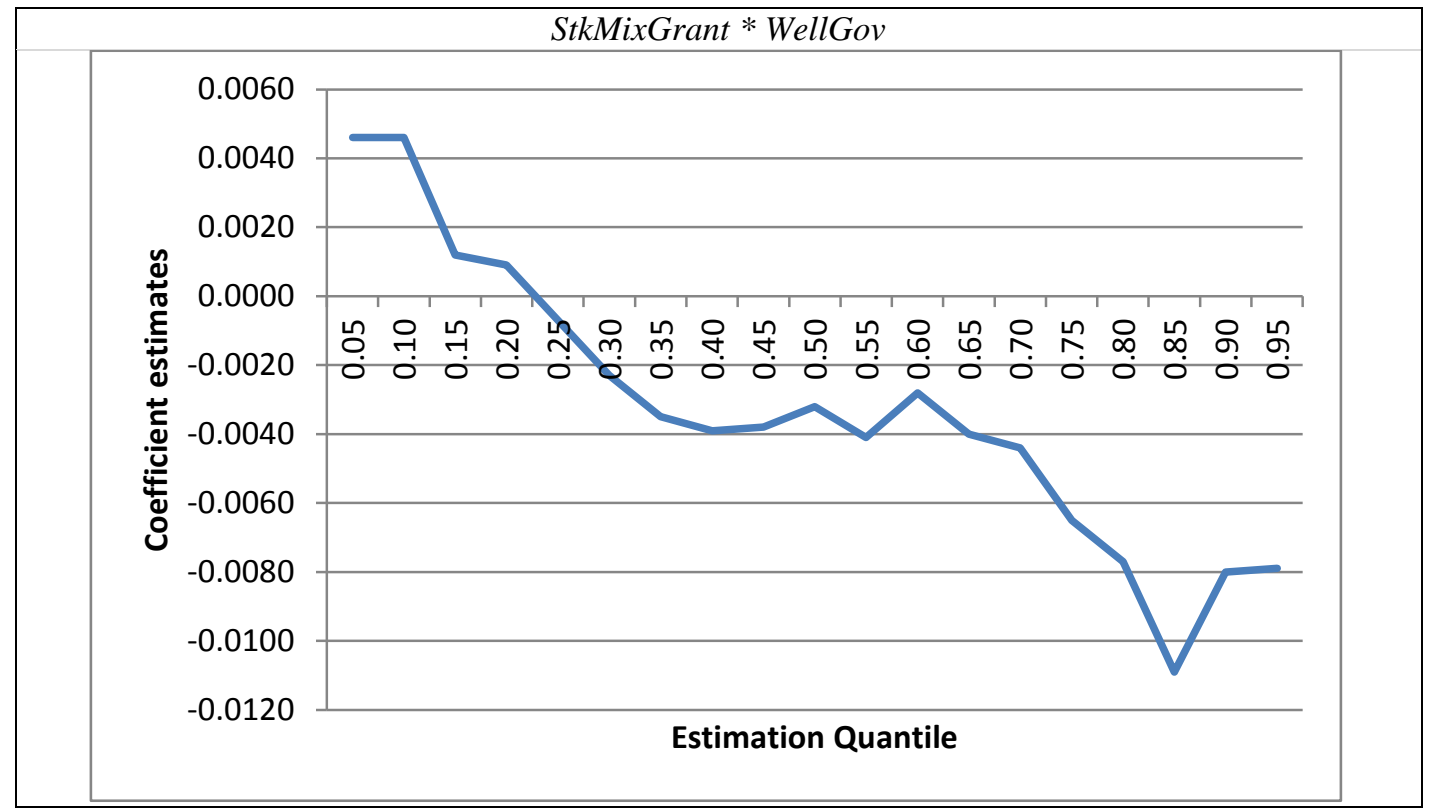

Coefficient plot for StkMixGrant * WellGov from quantile regression estimation of Desai and Dharmapala (2006) Table 4, Column (4). The following equation is estimated (Desai and Dharmapala, 2006, adjusted to include a mean effect for WellGov):

$$
\begin{aligned}
T S_{i, t}= & \beta_{0}+\beta_{1} S T K M I X G R A N T_{i, t}+\beta_{2}\left(W E L L G O V_{t} * S T K M I X G R A N T_{i, t}\right)+\text { Other Interaction Terms } \\
& + \text { Firm Fixed Effects }+ \text { Year Fixed Effects }+ \text { Controls }+v_{\mathrm{i}, \mathrm{t} .}
\end{aligned}
$$

$T S$ is the residual estimated from regressing the difference between book and tax income on total accruals (see Desai and Dharmapala, 2006 discussion, p. 159-160). StkMixGrant is the ratio of stock option grant value to total compensation for the firm's top five executives. WellGov is a dichotomous variable that equals one for firms that have a low governance index score (G-score less than or equal to 7) and equals zero otherwise. Estimation includes controlling for the level of deferred taxes and year, firm, and firm-year size fixed effects. 
Table 1

Panel A: Descriptive Statistics

\begin{tabular}{|c|c|c|c|c|c|c|}
\hline & $n$ & $\begin{array}{l}\text { Standard } \\
\text { Deviation }\end{array}$ & $\begin{array}{r}25^{\text {th }} \\
\text { percentile }\end{array}$ & Mean & Median & $\begin{array}{r}75^{\text {th }} \\
\text { percentile }\end{array}$ \\
\hline \multicolumn{7}{|l|}{ Tax Position } \\
\hline EndFin48Bal & 4,128 & 0.025 & 0.003 & 0.015 & 0.008 & 0.018 \\
\hline TAETR & 3,137 & 0.198 & -0.104 & -0.028 & -0.031 & 0.094 \\
\hline \multicolumn{7}{|c|}{ Governance and Incentives } \\
\hline NumFinExp & 4,128 & 1.273 & 1.000 & 1.711 & 1.000 & 3.000 \\
\hline PctIndep & 4,128 & 0.131 & 0.700 & 0.773 & 0.800 & 0.880 \\
\hline NumDirs & 4,128 & 2.182 & 8.000 & 9.082 & 9.000 & 10.000 \\
\hline CEOPortDelta (\$) & 4,128 & 606,123 & 39,818 & 330,331 & 129,767 & 355,567 \\
\hline CEOPortVega (\$) & 4,128 & 51,095 & 0.000 & 16,532 & 320 & 106,832 \\
\hline \multicolumn{7}{|l|}{ Controls } \\
\hline CFOps & 4,128 & 0.096 & 0.006 & 0.104 & 0.103 & 0.151 \\
\hline MVE (\$millions) & 4,128 & 25,979 & 532 & 8,418 & 1,647 & 5,419 \\
\hline ForAssets (\$millions) & 4,128 & 57,447 & 6 & 5,101 & 330 & 1,701 \\
\hline GeoComp & 4,128 & 1.852 & 0.324 & 0.628 & 0.541 & 0.985 \\
\hline
\end{tabular}


Table 1 (cont'd)

Panel B: Descriptive Statistics

\begin{tabular}{|c|c|c|}
\hline & Sample \% & Compustat \% \\
\hline \multicolumn{3}{|l|}{ Industry } \\
\hline Mining \& Construction & 2.09 & 4.09 \\
\hline Food & 2.55 & 2.06 \\
\hline Textiles, printing \& publishing & 5.25 & 2.86 \\
\hline Chemicals & 3.94 & 2.33 \\
\hline Pharmaceuticals & 5.18 & 6.69 \\
\hline Extractive Industries & 3.71 & 4.70 \\
\hline Durable Manufacturers & 26.67 & 16.71 \\
\hline Computers & 18.62 & 12.75 \\
\hline Transportation & 4.64 & 6.24 \\
\hline Utilities & 3.94 & 4.69 \\
\hline Retail & 10.90 & 7.16 \\
\hline Financial Institutions & 2.70 & 14.77 \\
\hline Insurance \& real estate & 1.00 & 5.37 \\
\hline Services & 8.42 & 7.62 \\
\hline Other & 0.39 & 1.94 \\
\hline Firm Characteristic & Sample Median & Compustat Median \\
\hline$R O A$ & 0.029 & $0.005^{* * *}$ \\
\hline Book to Mkt & 0.509 & $0.567^{* * * *}$ \\
\hline LT Debt/Assets & 0.156 & $0.078^{* * *}$ \\
\hline Sales/Assets & 0.826 & $0.590^{* * * *}$ \\
\hline$M V E$ & $1,084.391$ & $230.125^{* * *}$ \\
\hline
\end{tabular}

Industries are classified in accordance with Barth et al. (1998). Sample and Compustat observations are selected for fiscal year 2009, which provides the largest contribution of observations $(1,294)$ to the total estimation sample. ${ }^{* * *}$ denotes statistically significant median differences at the $1 \%$ levels using a Kolmogorov-Smirnov non-parametric test. 
Table 1

Panel C: Mean Incentives by Tax Avoidance Decile

\begin{tabular}{|c|c|c|c|c|c|c|c|c|c|c|}
\hline $\begin{array}{l}\text { EndFin } 48 B a l \\
\text { Decile }\end{array}$ & 1 & 2 & 3 & 4 & 5 & 6 & 7 & 8 & 9 & 10 \\
\hline \multicolumn{11}{|l|}{ Incentives } \\
\hline CEOPortDelta (\$) & 135,550 & 210,512 & 245,666 & 271,839 & 374,635 & 357,027 & 389,706 & 381,002 & 440,935 & 496,950 \\
\hline CEOPortVega (\$) & 10,791 & 9,112 & 13,002 & 15,121 & 16,504 & 20,934 & 14,654 & 17,420 & 21,761 & 26,040 \\
\hline
\end{tabular}


Table 1 (cont'd)

Panel D: Pearson Correlations

\begin{tabular}{|c|c|c|c|c|c|c|c|c|c|c|c|}
\hline & (1) & (2) & (3) & (4) & (5) & (6) & (7) & (8) & (9) & (10) & (11) \\
\hline \multirow{2}{*}{ EndFin48Bal (1) } & 1.0000 & 0.1264 & 0.0063 & -0.0953 & -0.0178 & 0.0170 & 0.0626 & -0.0015 & -0.0491 & 0.1031 & -0.0309 \\
\hline & & $<.0001$ & 0.6866 & $<.0001$ & 0.2532 & 0.2762 & $<.0001$ & 0.9239 & 0.0016 & $<.0001$ & 0.0474 \\
\hline \multirow{2}{*}{ TAETR (2) } & 0.1264 & 1.0000 & 0.0146 & -0.0110 & -0.0274 & -0.0428 & 0.0467 & -0.0243 & -0.1133 & 0.0352 & -0.0171 \\
\hline & $<.0001$ & & 0.4201 & 0.5432 & 0.1302 & 0.0183 & 0.0100 & 0.1796 & $<.0001$ & 0.0524 & 0.3452 \\
\hline \multirow{2}{*}{ PctIndep (3) } & 0.0063 & 0.0146 & 1.0000 & 0.1795 & 0.1859 & 0.1092 & 0.0898 & 0.1998 & 0.0117 & 0.2012 & -0.0332 \\
\hline & 0.6866 & 0.4201 & & $<.0001$ & $<.0001$ & $<.0001$ & $<.0001$ & $<.0001$ & 0.4507 & $<.0001$ & 0.0328 \\
\hline \multirow{2}{*}{ LogNumDirs (4) } & -0.0953 & -0.0110 & 0.1795 & 1.0000 & 0.2799 & 0.2833 & -0.0437 & 0.5540 & 0.0410 & 0.2954 & -0.0202 \\
\hline & $<.0001$ & 0.5432 & $<.0001$ & & $<.0001$ & $<.0001$ & 0.0050 & $<.0001$ & 0.0085 & $<.0001$ & 0.1953 \\
\hline \multirow{2}{*}{ LogNumFinExp (5) } & -0.0178 & -0.0274 & 0.1859 & 0.2799 & 1.0000 & 0.3265 & -0.0884 & 0.4189 & 0.1238 & 0.2295 & -0.0559 \\
\hline & 0.2532 & 0.1302 & $<.0001$ & $<.0001$ & & $<.0001$ & $<.0001$ & $<.0001$ & $<.0001$ & $<.0001$ & 0.0003 \\
\hline \multirow{2}{*}{ LogCEOPortDelta (6) } & 0.0170 & -0.0428 & 0.1092 & 0.2833 & 0.3265 & 1.0000 & -0.1571 & 0.6656 & 0.2635 & 0.3648 & -0.0192 \\
\hline & 0.2762 & 0.0183 & $<.0001$ & $<.0001$ & $<.0001$ & & $<.0001$ & $<.0001$ & $<.0001$ & $<.0001$ & 0.2168 \\
\hline \multirow{2}{*}{ LogCEOPortVega (7) } & 0.0626 & 0.0467 & 0.0898 & -0.0437 & -0.0884 & -0.1571 & 1.0000 & -0.2284 & -0.1210 & -0.0630 & 0.0384 \\
\hline & $<.0001$ & 0.0100 & $<.0001$ & 0.0050 & $<.0001$ & $<.0001$ & & $<.0001$ & $<.0001$ & $<.0001$ & 0.0136 \\
\hline \multirow{2}{*}{ LogMVE (8) } & -0.0015 & -0.0243 & 0.1998 & 0.5540 & 0.4189 & 0.6656 & -0.2284 & 1.0000 & 0.2818 & 0.4908 & -0.0419 \\
\hline & 0.9239 & 0.1796 & $<.0001$ & $<.0001$ & $<.0001$ & $<.0001$ & $<.0001$ & & $<.0001$ & $<.0001$ & 0.0070 \\
\hline \multirow{2}{*}{ CFOps (9) } & -0.0491 & -0.1133 & 0.0117 & 0.0410 & 0.1238 & 0.2635 & -0.1210 & 0.2818 & 1.0000 & 0.0722 & -0.0150 \\
\hline & 0.0016 & $<.0001$ & 0.4507 & 0.0085 & $<.0001$ & $<.0001$ & $<.0001$ & $<.0001$ & & $<.0001$ & 0.3370 \\
\hline \multirow{2}{*}{ LogForAssets (10) } & 0.1031 & 0.0352 & 0.2012 & 0.2954 & 0.2295 & 0.3648 & -0.0630 & 0.4908 & 0.0722 & 1.0000 & -0.1047 \\
\hline & $<.0001$ & 0.0524 & $<.0001$ & $<.0001$ & $<.0001$ & $<.0001$ & $<.0001$ & $<.0001$ & $<.0001$ & & $<.0001$ \\
\hline \multirow{2}{*}{ GeoComp (11) } & -0.0309 & -0.0171 & -0.0332 & -0.0202 & -0.0559 & -0.0192 & 0.0384 & -0.0419 & -0.0150 & -0.1047 & 1.0000 \\
\hline & 0.0474 & 0.3452 & 0.0328 & 0.1953 & 0.0003 & 0.2168 & 0.0136 & 0.0070 & 0.3370 & $<.0001$ & \\
\hline
\end{tabular}

EndFin48Bal is measured as the firm's ending balance of the uncertain tax benefit account (Compustat TXTUBEND), scaled by the firm's average assets over the period. TAETR is computed as the mean three-year GAAP ETR (computed as the firm's total tax expense scaled by pre-tax income) of the firm's size and industry peers minus the firm's three-year GAAP ETR. Size peers are firms within the same quintile of total assets and industry peers are firms within the same Fama-French 48 industry portfolios. PctIndep is the percentage of independent directors to total directors sitting on the board in the previous year (as indicated by Equilar). LogNumDirs is the natural logarithm of one plus the number of total directors sitting on the board in the previous year (as indicated by Equilar). LogNumFinExp is the natural logarithm of one plus the number of financial experts designated on the board of directors in the year preceding the fiscal year (as indicated by RiskMetrics). CEOPortDelta (CEOPortVega) is the (risk-neutral) dollar change in the 
firm CEO's equity portfolio value for a $1 \%$ change in the value (volatility) of the firm's stock price (Core and Guay, 2002). LogCEOPortDelta (LogCEOPortVega) is the natural logarithm of CEOPortDelta (CEOPortVega). LogMVE is the natural logarithm of market value of equity computed for the fiscal year. CFOps is cash flow from operations divided by average total assets. LogForAssets is the natural logarithm of total foreign assets computed for the fiscal year. GeoComp is a revenue-based Hirfindahl-Hirschman index that captures within-firm geographic segment complexity

(Bushman

et

al., 2004)

computed

for

the

fiscal

year. 
Table 2

Panel A: CEO Incentives

\begin{tabular}{|c|c|c|c|c|c|c|c|c|}
\hline \multirow[t]{2}{*}{$\begin{array}{c}\text { TaxPosition }= \\
n= \\
X=\end{array}$} & \multicolumn{2}{|c|}{$\begin{array}{c}\text { EndFin48Bal } \\
4,128 \\
\text { LogCEOPortDelta }\end{array}$} & \multicolumn{2}{|c|}{$\begin{array}{c}\text { TAETR } \\
3,137 \\
\text { LogCEOPortDelta }\end{array}$} & \multicolumn{2}{|c|}{$\begin{array}{c}\text { EndFin48Bal } \\
4,128 \\
\text { LogCEOPortVega }\end{array}$} & \multicolumn{2}{|c|}{$\begin{array}{c}\text { TAETR } \\
3,137 \\
\text { LogCEOPortVega }\end{array}$} \\
\hline & Coef. & $t$-stat & Coef. & $t$-stat & Coef. & $t$-stat & Coef. & $t$-stat \\
\hline$O L S$ & 0.0001 & 0.46 & -0.0035 & -1.56 & 0.0004 & 4.44 & 0.0014 & 1.69 \\
\hline \multicolumn{9}{|l|}{ Quantile } \\
\hline 0.10 & 0.0001 & 3.00 & -0.0051 & -2.30 & 0.0000 & 4.02 & -0.0031 & -2.66 \\
\hline 0.20 & 0.0002 & 3.33 & -0.0031 & -1.68 & 0.0001 & 4.81 & -0.0006 & -0.87 \\
\hline 0.30 & 0.0002 & 2.35 & -0.0014 & -0.88 & 0.0001 & 5.59 & 0.0010 & 1.84 \\
\hline 0.40 & 0.0001 & 1.03 & -0.0011 & -1.06 & 0.0001 & 3.35 & 0.0014 & 2.35 \\
\hline 0.50 & 0.0002 & 1.37 & -0.0014 & -1.12 & 0.0002 & 3.69 & 0.0022 & 3.85 \\
\hline 0.60 & 0.0003 & 1.36 & -0.0019 & -1.22 & 0.0002 & 5.40 & 0.0033 & 5.04 \\
\hline 0.70 & 0.0001 & 0.21 & -0.0024 & -1.30 & 0.0004 & 4.70 & 0.0045 & 5.65 \\
\hline 0.80 & 0.0002 & 0.64 & -0.0004 & -0.15 & 0.0006 & 4.70 & 0.0049 & 4.85 \\
\hline 0.90 & 0.0008 & 1.94 & -0.0013 & -0.44 & 0.0009 & 5.02 & 0.0030 & 3.21 \\
\hline Avg Pseudo $R^{2}$ & & 0.039 & & 0.046 & & 0.039 & & 0.000 \\
\hline$Q(0.80)=Q(0.20)$ & & 0.989 & & 0.309 & & 0.000 & & 0.000 \\
\hline$Q(0.90)=Q(0.10)$ & & 0.097 & & 0.213 & & 0.000 & & 0.000 \\
\hline$Q(0.90)=Q(0.50)$ & & 0.144 & & 0.975 & & 0.002 & & 0.301 \\
\hline$Q(0.10)=Q(0.50)$ & & 0.374 & & 0.044 & & 0.000 & & 0.018 \\
\hline
\end{tabular}

Panel B: Board Expertise and Independence

\begin{tabular}{|c|c|c|c|c|c|c|c|c|}
\hline \multirow[t]{2}{*}{$\begin{array}{c}\text { TaxPosition }= \\
n= \\
X=\end{array}$} & \multicolumn{2}{|c|}{$\begin{array}{c}\text { EndFin48Bal } \\
4,128 \\
\text { LogNumFinExp }\end{array}$} & \multicolumn{2}{|c|}{$\begin{array}{c}\text { TAETR } \\
\text { 3,137 } \\
\text { LogNumFinExp }\end{array}$} & \multicolumn{2}{|c|}{$\begin{array}{c}\text { EndFin48Bal } \\
4,128 \\
\text { PctIndep } \\
\end{array}$} & \multicolumn{2}{|c|}{$\begin{array}{c}\text { TAETR } \\
3,137 \\
\text { PctIndep } \\
\end{array}$} \\
\hline & Coef. & $t$-stat & Coef. & $t$-stat & Coef. & $t$-stat & Coef. & $t$-stat \\
\hline$O L S$ & -0.0009 & -0.96 & -0.0089 & -1.08 & -0.0014 & -0.46 & 0.0103 & 0.37 \\
\hline \multicolumn{9}{|l|}{ Quantile } \\
\hline 0.10 & 0.0005 & 5.58 & 0.0152 & 1.08 & 0.0009 & 2.50 & -0.0274 & -0.84 \\
\hline 0.20 & 0.0008 & 6.57 & 0.0056 & 0.73 & 0.0005 & 0.88 & 0.0236 & 0.97 \\
\hline 0.30 & 0.0007 & 3.59 & 0.0011 & 0.18 & 0.0015 & 2.13 & 0.0275 & 1.55 \\
\hline 0.40 & 0.0009 & 2.30 & -0.0044 & -0.67 & 0.0021 & 2.04 & 0.0384 & 2.30 \\
\hline 0.50 & 0.0006 & 1.33 & -0.0120 & -1.85 & 0.0025 & 2.14 & 0.0426 & 2.01 \\
\hline 0.60 & 0.0004 & 0.61 & -0.0144 & -1.91 & 0.0014 & 0.61 & 0.0388 & 1.68 \\
\hline 0.70 & 0.0004 & 0.55 & -0.0167 & -2.41 & 0.0023 & 0.95 & 0.0153 & 0.48 \\
\hline 0.80 & -0.0008 & -0.69 & -0.0100 & -0.99 & 0.0043 & 1.35 & 0.0021 & 0.05 \\
\hline 0.90 & -0.0040 & -1.94 & -0.0027 & -0.32 & -0.0009 & -0.15 & -0.0707 & -2.28 \\
\hline Avg Pseudo $R^{2}$ & & 0.039 & & 0.046 & & 0.039 & & 0.046 \\
\hline$Q(0.80)=Q(0.20)$ & & 0.173 & & 0.254 & & 0.215 & & 0.425 \\
\hline$Q(0.90)=Q(0.10)$ & & 0.014 & & 0.394 & & 0.174 & & 0.604 \\
\hline$Q(0.90)=Q(0.50)$ & & 0.011 & & 0.314 & & 0.568 & & 0.005 \\
\hline$Q(0.10)=Q(0.50)$ & & 0.772 & & 0.125 & & 0.094 & & 0.016 \\
\hline
\end{tabular}


Table 2 (cont'd)

Panel C: Control Variables

\begin{tabular}{|c|c|c|c|c|c|c|c|c|c|c|}
\hline \multirow[t]{2}{*}{$\begin{array}{c}\text { TaxPosition }= \\
n= \\
X=\end{array}$} & \multicolumn{2}{|c|}{$\begin{array}{c}\text { EndFin } 48 \text { Bal } \\
\text { 4,128 } \\
\text { LogNumDirs }\end{array}$} & \multicolumn{2}{|c|}{$\begin{array}{c}\text { EndFin } 48 \text { Bal } \\
4,128 \\
\text { LogMVE }\end{array}$} & \multicolumn{2}{|c|}{$\begin{array}{c}\text { EndFin } 48 \mathrm{Bal} \\
4,128 \\
\text { CFOps }\end{array}$} & \multicolumn{2}{|c|}{$\begin{array}{c}\text { EndFin } 48 \text { Bal } \\
\text { 4,128 } \\
\text { LogForAssets }\end{array}$} & \multicolumn{2}{|c|}{$\begin{array}{c}\text { EndFin48Bal } \\
4,128 \\
\text { GeoComp } \\
\end{array}$} \\
\hline & Coef. & $t$-stat & Coef. & $t$-stat & Coef. & $t$-stat & Coef. & $t$-stat & Coef. & $t$-stat \\
\hline$O L S$ & -0.0159 & -8.26 & $\overline{0.0008}$ & 2.07 & -0.0155 & -3.68 & $\mathbf{0 . 0 0 1 0}$ & 7.29 & -0.0003 & -1.47 \\
\hline Quantile & & & & & & & & & & \\
\hline 0.10 & 0.0002 & 1.04 & 0.0000 & 0.37 & 0.0006 & 1.76 & 0.0002 & 6.50 & -0.0001 & -0.48 \\
\hline 0.20 & -0.0004 & -1.21 & 0.0002 & 3.00 & 0.0007 & 1.57 & 0.0003 & 7.31 & -0.0002 & -0.49 \\
\hline 0.30 & -0.0010 & -2.57 & 0.0004 & 3.72 & 0.0008 & 1.05 & 0.0005 & 8.65 & -0.0000 & -0.07 \\
\hline 0.40 & -0.0020 & -3.05 & 0.0005 & 2.63 & 0.0006 & 0.34 & 0.0006 & 7.87 & -0.0001 & -0.06 \\
\hline 0.50 & -0.0050 & -4.36 & 0.0008 & 4.31 & -0.0012 & -0.57 & 0.0007 & 5.32 & -0.0001 & -0.08 \\
\hline 0.60 & -0.0094 & -7.68 & 0.0013 & 4.62 & -0.0025 & -0.95 & 0.0008 & 4.67 & -0.0002 & -0.09 \\
\hline 0.70 & -0.0136 & -7.92 & 0.0016 & 4.02 & -0.0041 & -0.75 & 0.0009 & 4.06 & -0.0002 & -0.09 \\
\hline 0.80 & -0.0177 & -6.22 & 0.0018 & 3.35 & -0.0118 & -1.67 & 0.0013 & 3.65 & -0.0002 & -0.04 \\
\hline 0.90 & -0.0349 & -8.28 & 0.0024 & 2.66 & -0.0291 & -2.54 & 0.0015 & 2.93 & -0.0004 & -0.07 \\
\hline
\end{tabular}

\begin{tabular}{|c|c|c|c|c|c|c|c|c|c|c|}
\hline \multirow[t]{2}{*}{$\begin{array}{c}\text { TaxPosition }= \\
n= \\
X=\end{array}$} & \multicolumn{2}{|c|}{$\begin{array}{c}\text { TAETR } \\
\text { 3,137 } \\
\text { LogNumDirs }\end{array}$} & \multicolumn{2}{|c|}{$\begin{array}{c}\text { TAETR } \\
3,137 \\
\text { LogMVE }\end{array}$} & \multicolumn{2}{|c|}{$\begin{array}{c}\text { TAETR } \\
3,137 \\
C F O p s\end{array}$} & \multicolumn{2}{|c|}{$\begin{array}{c}\text { TAETR } \\
\text { 3,137 } \\
\text { LogForAssets }\end{array}$} & \multicolumn{2}{|c|}{$\begin{array}{c}\text { TAETR } \\
3,137 \\
\text { GeoComp }\end{array}$} \\
\hline & Coef. & $t$-stat & Coef. & $t$-stat & Coef. & $t$-stat & Coef. & $t$-stat & Coef. & $t$-stat \\
\hline$O L S$ & -0.0175 & -0.98 & 0.0036 & 1.05 & -0.2108 & -5.77 & 0.0033 & 2.71 & -0.0015 & -0.90 \\
\hline \multicolumn{11}{|l|}{ Quantile } \\
\hline 0.10 & -0.0367 & -1.43 & 0.0324 & 7.86 & -0.0298 & -0.51 & -0.0051 & -3.63 & -0.0027 & -0.34 \\
\hline 0.20 & 0.0023 & 0.18 & 0.0167 & 6.39 & -0.1879 & -4.48 & 0.0001 & 0.11 & -0.0048 & -0.56 \\
\hline 0.30 & 0.0103 & 0.81 & 0.0100 & 4.86 & -0.2257 & -7.74 & 0.0024 & 2.49 & -0.0059 & -0.59 \\
\hline 0.40 & 0.0028 & 0.22 & 0.0077 & 3.61 & -0.2800 & -12.12 & 0.0045 & 3.97 & -0.0066 & -0.45 \\
\hline 0.50 & 0.0043 & 0.41 & 0.0003 & 0.14 & -0.2975 & -9.11 & 0.0064 & 6.53 & -0.0073 & -0.65 \\
\hline 0.60 & -0.0163 & -1.06 & -0.0072 & -2.95 & -0.3026 & -9.23 & 0.0090 & 9.17 & -0.0043 & -0.51 \\
\hline 0.70 & -0.0182 & -0.89 & -0.0137 & -5.27 & -0.2797 & -8.58 & 0.0108 & 11.14 & 0.0024 & 0.38 \\
\hline 0.80 & -0.0053 & -0.21 & -0.0228 & -6.14 & -0.2592 & -4.18 & 0.0115 & 8.23 & 0.0015 & 0.25 \\
\hline 0.90 & 0.0310 & 1.37 & -0.0220 & -5.54 & -0.1709 & -2.95 & 0.0039 & 2.23 & 0.0006 & 0.08 \\
\hline
\end{tabular}

EndFin48Bal is measured as the firm's ending balance of the uncertain tax benefit account (Compustat TXTUBEND), scaled by the assets. TAETR is computed as the mean three-year GAAP ETR (computed as the firm's total tax expense scaled by pre-tax income) of the firm's size and industry peers minus the firm's three-year GAAP ETR. Size peers are firms within the same quintile of total assets and industry peers are firms within the same FamaFrench 48 industry portfolios. PctIndep is the percentage of independent directors to total directors sitting on the board in the previous year (as indicated by Equilar). LogNumFinExp is the natural logarithm of one plus the number of financial experts designated on the board of directors in the year preceding the fiscal year (as indicated by RiskMetrics). CEOPortDelta (CEOPortVega) is the (risk-neutral) dollar change in the firm CEO's equity portfolio value for a $1 \%$ change in the value (volatility) of the firm's stock price (Core and Guay, 2002). LogCEOPortDelta (LogCEOPortVega) is the natural logarithm of one plus CEOPortDelta (CEOPortVega). Two-sided p-values are reported for the tests of coefficient differences between quintiles 0.80 vs. 0.20 and 0.90 vs. 0.10 . 
Table 3

\section{Desai and Dharmapala (2006) Quantile Regression}

Table 4 (All Firms)

\begin{tabular}{|c|c|c|c|c|c|c|}
\hline & \multicolumn{2}{|c|}{ StkMixGrant } & \multicolumn{2}{|c|}{ WellGov } & \multicolumn{2}{|c|}{ StkMixGrant $*$ WellGov } \\
\hline & Coef. & $t$-stat & Coef. & $t$-stat & Coef. & $t$-stat \\
\hline$O L S$ & -0.0086 & -1.60 & 0.0323 & 0.57 & 0.0016 & 0.18 \\
\hline \multicolumn{7}{|l|}{ Quantile } \\
\hline 0.05 & 0.0025 & 1.50 & 0.0081 & 0.01 & 0.0046 & 1.11 \\
\hline 0.10 & 0.0025 & 0.86 & 0.0081 & 0.01 & 0.0046 & 0.76 \\
\hline 0.15 & 0.0029 & 0.82 & 0.0102 & 0.01 & 0.0012 & 0.15 \\
\hline 0.20 & 0.0022 & 0.56 & 0.0081 & 0.01 & 0.0009 & 0.11 \\
\hline 0.25 & 0.0020 & 0.50 & 0.0090 & 0.03 & -0.0007 & -0.09 \\
\hline 0.30 & 0.0012 & 0.34 & 0.0175 & 0.13 & -0.0023 & -0.27 \\
\hline 0.35 & 0.0006 & 0.16 & 0.0186 & 0.29 & -0.0035 & -0.50 \\
\hline 0.40 & 0.0000 & 0.01 & 0.0064 & 0.12 & -0.0039 & -0.47 \\
\hline 0.45 & -0.0002 & -0.07 & 0.0044 & 0.09 & -0.0038 & -0.51 \\
\hline 0.50 & -0.0004 & -0.11 & 0.0016 & 0.04 & -0.0032 & -0.45 \\
\hline 0.55 & 0.0007 & 0.24 & -0.0004 & -0.01 & -0.0041 & -0.60 \\
\hline 0.60 & 0.0011 & 0.36 & 0.0079 & 0.18 & -0.0028 & -0.41 \\
\hline 0.65 & 0.0014 & 0.35 & 0.0086 & 0.15 & -0.0040 & -0.52 \\
\hline 0.70 & 0.0015 & 0.39 & 0.0048 & 0.04 & -0.0044 & -0.63 \\
\hline 0.75 & 0.0023 & 0.53 & 0.0065 & 0.02 & -0.0065 & -0.84 \\
\hline 0.80 & 0.0022 & 0.53 & 0.0059 & 0.01 & -0.0077 & -0.80 \\
\hline 0.85 & 0.0014 & 0.46 & 0.0211 & 0.02 & -0.0109 & -1.65 \\
\hline 0.90 & -0.0006 & -0.24 & 0.0253 & 0.02 & -0.0080 & -1.52 \\
\hline 0.95 & -0.0006 & -0.47 & 0.0262 & 0.02 & -0.0079 & -2.65 \\
\hline
\end{tabular}

Replication of Desai and Dharmapala (2006) Table 4, Column (4) using quantile regression estimation. The following equation is estimated (equation 17 from Desai and Dharmapala, 2006, adjusted to include a mean effect for WellGov which was mistakenly excluded from their specification):

$$
\begin{aligned}
T S_{i, t}= & \beta_{0}+\beta_{1} \text { STKMIXGRANT }_{i, t}+\beta_{2}\left(\text { WELLGOV }_{i} * S T K M I X G R A N T_{i, t}\right) \\
& + \text { Other Interaction Terms }+ \text { Firm Fixed Effects }+ \text { Year Fixed Effects + Controls }+v_{i, t}
\end{aligned}
$$

$T S$ is the residual estimated from regressing the difference between book and tax income on total accruals (see Desai and Dharmapala, 2006, 159-160). StkMixGrant is the ratio of stock option grant value to total compensation for the firm's top five executives. WellGov is a dichotomous variable that equals one for firms that have a low governance index score (G-score less than or equal to 7) and equals zero otherwise. Estimation includes controlling for the level of deferred taxes and year, firm, and firm-year size fixed effects. 